\title{
Multi-objective interior design optimization method based on sustainability concepts for post-disaster temporary housing units
}

\author{
S.M. Amin Hosseini ${ }^{\mathrm{a}, *}$, Reza Yazdani ${ }^{\mathrm{b}}$, Albert de la Fuente ${ }^{\mathrm{a}}$ \\ a Department of Civil and Environmental Engineering, Universitat Politècnica de Catalunya (UPC), Jordi Girona 1-3, 08034, Barcelona, Spain \\ ${ }^{\mathrm{b}}$ Department of Computer Architecture, Universitat Politècnica de Catalunya (UPC), Jordi Girona 1-3, 08034, Barcelona, Spain
}

\section{A R T I C L E I N F O}

\section{Keywords}

Post-disaster temporary housing

Sustainability

Building interior design

Bam

MIVES

Computer-aided design

Optimization

\begin{abstract}
A B S T R A C T
Temporary housing units (THUs), which are provided after disasters, are crucial in terms of sustainability pillars (economic, social, and environmental). In general, THUs, which are regular houses with minimum space and facilities, incorporate some negative aspects of the building industry. Additionally, as large numbers of THUs are usually provided in a short time and under emergency situations, some negative impacts of these units escalate. In this context, this study aims at reducing some negative impacts of THUs by applying a novel optimization model that maximises sustainability indexes by simulating the design of interior geometries for THUs. This method is based on the coupling of artificial intelligence and a multi-criteria decision-making model for sustainability assessment. The proposed model generates optimal solutions using a backtracking algorithm together with a binary search. To evaluate the sustainability indexes, an Integrated Value Model for Sustainability Assessment (MIVES) is applied. This novel method enables decision makers to automatically generate the most suitable alternative solutions for the early design stage of THUs. The results confirm that small changes in the interior geometric design can remarkably affect the sustainability indexes of THUs.
\end{abstract}

\section{Introduction}

The total displaced population (DP) is expected to increase in the near future, owing to increases in both climate-related hazards and social vulnerability [1]. The DP needs somewhere to live while their permanent housing is being reconstructed, or until they find alternative permanent accommodations [2,3]. Temporary housing is often utilised in the social process of recovery programs and associated physical housing [4]. One type of such physical housing is temporary housing units (THUs), such as prefabricated units and on-site masonry units, that are erected after events. THUs have been utilised after many major disasters [4-9]. However, according to Refs. [10-19], THUs have been criticised because of economic, social, and environmental issues. As these researchers discussed, the main problems of THUs are as follows: they require large public expenditures that can be used for permanent housing; they prolong the permanent reconstruction time; they often do not match the culture of the DP; and they involve minimum community participation and negative environmental effects.

Additionally, according to Refs. [ [20,21]], the building industry uses considerable amounts of energy, raw materials, and water, and creates $\mathrm{CO}_{2}$ emissions during the building life cycle. THUs embrace most of the negative aspects of normal buildings. However, the sizes of THUs are usually smaller than normal residential buildings, as providing massive numbers of units could have substantial negative impacts. Furthermore, the life services of THUs are much lower than those of normal buildings. Consequently, THUs could have considerable negative features. In this context, Atmaca [19] mentioned that there could be a major opportunity to reduce resource consumption and greenhouse gas emissions by minimizing the negative impacts of THUs, considering the incremental trend of producing/using these units in recent decades.

Thus, a question that arises is why decision makers provide these units, with negative features, to accommodate the DP. To answer this question, it should be noted that decision makers are forced to choose them based on the special conditions, potential, obstacles, and limitations of the affected area and populations. Therefore, to respond to the needs of the DP and to manage the aforementioned issues, there are two approaches: (1) finding alternatives that are more suitable to replace the THUs, and (2) decreasing the negative features of the THUs. However, when there are no other alternatives to THUs, to meet all

Abbreviations: THU, Temporary housing unit; TH, Temporary housing; DP, Displaced population; W, Wall; K, Kitchen; B, Bathroom; L, Living room; E, Entrance; DMT, Decision-mak-

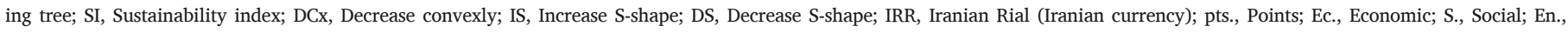
Environmental.

${ }^{*}$ Corresponding author.

E-mail addresses: amin.hosseini@upc.edu (S.M.Amin Hosseini); reza.yazdani@upc.edu (R. Yazdani); albert.de.la.fuente@upc.edu (A.d.l. Fuente) 
the demands of the DPs found in previous cases, it is necessary to try to minimise the negative impacts of THUs.

A main problem of THUs is the interior architectural design of these units; however, there is very little research on this problem. Evans \& McCoy [22] declared that interior architectural dimensions could have an impact on human psychological stress. The importance of this problem is more evident when DPs are forced to live in these units for several years. Additionally, according to Yi \& Malkawi [23], a building's geometric variables, including the dimensions and heights that form the area and volume of the building, have an impact on other aspects, such as energy consumption. Moreover, according to Atmaca \& Atmac [24], the walls and floors of the THUs comprise a major part of the total construction cost. Thus, the interior design problems of THUs could have a considerable impact on the three pillars of sustainability. In this regard, it is necessary to assess the interior design of THUs to increase the satisfaction of DPs in two areas: (1) to assist in reducing the psychological stress of DPs and to mollify their sufferings, and (2) to avoid the rejection of THUs by DPs, which increases the negative impacts of these units. In addition, it is also desired to decrease the economic and environmental impacts of THUs.

The main objective of this research is to optimise the sustainability index (SI) of THUs by simulating the sizing of interior spaces. Indeed, this study is aimed at minimizing the environmental and economic negative impacts of THUs, while maximizing the satisfaction of social requirements. In other words, this research will permit designers and decision makers to achieve optimal SIs by automatically generating the most suitable sizing for interior spaces, with both the construction technology (materials and process) and plan topology (spatial relations) remaining unchanged.

According to Arvin \& House [25], the space-planning problem can be categorised into two groups: topological and geometric problems. This research focuses on geometric problems, especially on the horizontal geometry. Additionally, as the interior design of buildings can embrace a wide range of possible solutions, computational methods for design optimization could assist decision makers in generating and filtering appropriate alternatives. To this end, a combination of artificial intelligence and a multi-criteria decision-making model is applied for the sustainability assessment. Additionally, as the relative importance (weight) of the sustainability pillars could be different for each case, this study uses an indicator-weighting system.

The remainder of this paper is organised into four parts: (1) Section 2, a literature review; (2) Section 3, a case study considering the temporary housing program aftermath of an earthquake in Bam, a city in southeastern Iran, 2003; (3) Section 4, the model design, which pre- sents a newly designed model based on a backtracking algorithm together with a binary search approach and an integrated value model for sustainability assessment (MIVES); and (4) Sections 5-7, the model application and results.

\section{Literature review}

There are numerous studies focused on the impacts of THUs. However, there is little research to support decision makers in terms of finding an optimal THU [14]. It should be noted that, to the best of the authors' knowledge, there is no research that presents a sustainability optimization method oriented to the design of THUs. However, some researchers have developed optimization tools to solve temporary housing problems, but in other areas (e.g., site location problem). In this case, El-Anwar et al. [26] presented an automated system to assist decision makers by determining optimal temporary housing arrangements. This system was designed to minimise negative socioeconomic impacts. Hosseini et al. [27] applied a combination of a multi-criteria decision-making method (MCDM) called MIVES and a knapsack algorithm to identify the most suitable site locations for THUs by maximizing the SI. El-Anwar \& Chen [28] designed a computational model based on a Hungarian algorithm to optimise temporary resettlement problems by focusing on socioeconomic issues, and El-Anwar [29] conducted an optimization process by using genetic algorithms and an integer-programming model to evaluate the socioeconomic benefits of a temporary housing program.

Evins [30] stated that the number of research studies on optimization problems for sustainable building design has considerably increased. Table 1 lists the studies devoted to the optimization of building components and indicators.

According to Table 1, most of the optimization methods have focused on the environmental performance of buildings, especially energy issues. Evins [30] stated that most of the publications considered single-objective problems. Indeed, it must be remarked that the optimization processes in these studies only embrace one or some of the SI indicators, whereas other relevant indicators were disregarded.

Additionally, few studies considered buildings' interior design problems in the context of sustainability. Some studies considered space-planning problems, such as topological and geometric problems. Nonetheless, most of these were studies conducted based on architectural design problems, not sustainability issues. For instance, Balachandran \& Gero [40] designed a new multi-criteria optimization methodology for the dimensions of architectural floor plans considering three objectives, including minimizing construction cost, maximizing floor area, and maximizing aspect ratio. Previously, Merrell et al. [41]

Table 1

Previous research studies considering the design optimization problem.

\begin{tabular}{|c|c|c|c|c|c|}
\hline Authors & Optimization & Optimization Method & Variable & $\begin{array}{l}\text { Simulated } \\
\text { Component }\end{array}$ & Case \\
\hline Adamski [31], & $\begin{array}{l}\text { Construction Cost \& Energy } \\
\text { Consumption }\end{array}$ & - & Exterior Partition & Shape of Oval Plan & Residential \\
\hline Caldas \& Norford [32], & Thermal and Lighting Performance & Genetic Algorithms & Windows Features & Envelope & Office \\
\hline Hasan et al. [33], & Life Cycle Cost & $\begin{array}{l}\text { Hooke-Jeeves } \\
\text { algorithm }\end{array}$ & Construction Layers & Envelope & Residential \\
\hline Jin \& Jeong [34], & Thermal Performance & Genetic Algorithms & Top \& Bottom Length, Height, Angles & Shape & - \\
\hline $\begin{array}{l}\text { Kämpf \& Robinson } \\
\text { [35], }\end{array}$ & Solar Energy Utilization & Hybrid CMA-ES/HDE & Shape Geometry & Urban Form & - \\
\hline Marks [36], & $\begin{array}{l}\text { Construction Cost \& Energy } \\
\text { Consumption }\end{array}$ & - & External Wall Features & Shape & - \\
\hline Ordóñez \& Modi [37], & Energy Consumption \& $\mathrm{CO}_{2}$ Emission & - & Floors Number & Shape & Residential \\
\hline Wang et al. [38], & Life Cycle Cost \& Energy & Genetic Algorithms & $\begin{array}{l}\text { Construction Layers, Orientation, } \\
\text { Material }\end{array}$ & Shape, Material & Office \\
\hline Wang et al. [39], & Life Cycle Cost \& Energy & Genetic Algorithms & Construction Layers, Orientation, & Envelope & Office \\
\hline Yi \& Malkawi [23], & Energy Consumption & Genetic Algorithms & External Wall Geometry & From & - \\
\hline
\end{tabular}


used linear programming to overcome dimensioning problems of mobile homes. As another example, Merrell et al. [42] presented a new approach to automatically generate residential building design by using the Metropolis algorithm. Nevertheless, Merrell et al. [42] did not consider client-specific factors. Arvin \& House [25] designed a prototype system to solve space planning problems by providing designers control of generated solutions. Bahrehmand et al. [43] presented a new model for determining an ideal layout by maximizing quality functions using an evolutionary algorithm. Other research studies considered the 3D space layout of buildings. For instance, Yi et al. [44] suggested a new decision-making method for solving 3D space layout problems. Bao et al. [45] presented an approach to determining the most suitable shape layout of buildings from among possible solutions, based on guidelines and functional quality measures. Finally, other authors have considered the furniture layout system in building interior problems, such as Merrell et al. [46].

\section{Case study}

On the $26^{\text {th }}$ of December 2003, an earthquake occurred in Bam, a city in Southeastern Iran. Bam's population was approximately 100,000 pre-disaster [47], in an area of $19,374 \mathrm{~km}^{2}$ [48]. It is estimated that $80 \%$ of the buildings were completely destroyed [49], approximately $30 \%$ of Bam's population died [50], and approximately 75,000 people lost their homes [ [51,52]]. In the aftermath of the Bam earthquake, THUs were used to accommodate the DP.

In the Bam case, the decision makers had to choose THUs because of the following reasons: (1) a large DP, (2) a lack of other possibilities, (3) climatic conditions, and (4) the cultural conditions of the DP. Therefore, the TH program was performed as an intermediate phase of the Bam recovery that included three phases: (1) tent shelters, (2) intermediate shelter, and (3) permanent housing phase [52]. To this end, contractors were requested to supply a vast number of THUs with different technologies for the DP. According to Refs. [ [48,53]], 35,905 units of THUs were built, 26,900 on private properties, and 9005 in 23 camps.

The Iranian government introduced the Housing Foundation of Islamic Republic of Iran (HFIR) and the Ministry of Defence as a responsible for providing the TH. These two organizations provided THUs directly or via hiring contractors [52]. The experts from the HFIR designed eight alternatives for THUs, based on four external walls, two roofing technologies, and light steel structures. The designed THUs had 18,20 , and $36 \mathrm{~m}^{2}$ area alternatives, with different plans.

The wall technologies were (1) autoclaved aerated concrete blocks; (2) concrete masonry units (CMUs); (3) 3D sandwich panels, each of which comprises a polystyrene core sandwiched between two welded steel wire meshes [54]; and (4) a pressed reeds panel that could be covered with different plasters, such as concrete and gypsum plaster, as shown in Fig. 1.

These eight alternatives had already been assessed by Hosseini et al. [55] to determine the SI of each one. The results of the assessment of these alternatives demonstrated that the CMUs obtained the highest
SI. Additionally, a considerable amount of this technology had been applied after the Bam earthquake. In this regard, this study considers a CMU of $20 \mathrm{~m}^{2}$, which is shown in Fig. 2, as a case study.

In addition to the general problems of THUs previously discussed, $10-20 \%$ of these THUs were vacant [56], and took a considerable amount of time to be delivered. Furthermore, the TH program cost reached $\$ 60$ million [56], and there was no specified plan for a second life for the THUs. Additionally, the DP remained in these units for several years until the construction of the permanent housing was finished. In this case, the THUs played the role of permanent housing for some of the DP.

\section{Model design}

According to Radford \& Gero [57], optimization models for building problems explore all feasible solutions to determine the most suitable ones based on defined goals. Thus, this research presents a novel optimization model that automatically generates alternatives with different geometrical floor plan designs as feasible solutions. The objective is to obtain the optimal SI by varying the horizontal interior dimensions of the THU. The MIVES is applied to evaluate the SIs of the alternatives. The MIVES is a MCDM, and includes a value function based on the utility theory. The main framework of the model is developed based on a backtracking algorithm, which is applied for non-linear and complicated numerical optimization problems (see [ [58,59]]). However, other algorithms, such as the shoelace algorithm, are used within the main framework.

\subsection{Defining parameters of the temporary housing unit (THU) (case study)}

The floor plan of the THU (CMU) applied in Bam was assumed for initializing the layout, to specify parameters. This plan contains four interior spaces surrounded by walls as boundaries (Fig. 2): living room, kitchen, entrance, and bathroom. The parameters to be considered are categorised into geometry and construction materials.

Solutions with different geometries are generated by sliding walls (see Fig. 3). Codes were assigned to name the walls (W) of each space: entrance (E), kitchen (K), living room (L), and bathroom (B); the indexes refer to the wall number. Additionally, arrows labelled on the edges represent sliding walls and directions. For instance, arrow $\mathrm{k}_{2}$ indicates that $\mathrm{WK}_{2}$ can be slid forward and backward. Additionally, as shown in Fig. 3 , the nodes on the vertexes of the edges are used to define the geometrical parameters of each edge for the computerised model.

To determine the variation ranges of the walls length parameters, in other words, the possible range of the sliding walls, two approaches have been conducted: (1) using both national and international codes, and (2) interviewing experts. In the first approach, the minimum required areas of the interior spaces are specified based on emergency shelters and normal residential buildings from the national and international codes.

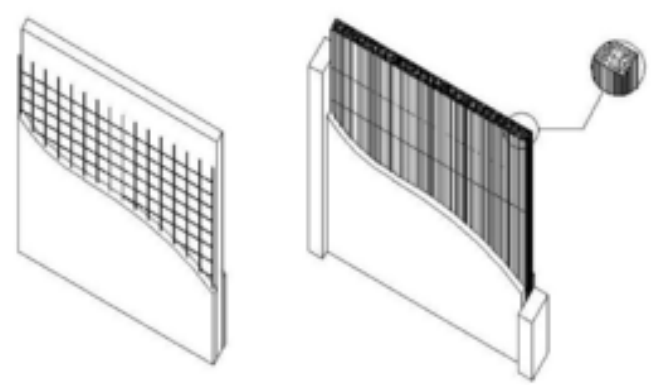

Fig. 1. View of the four wall technologies; (a) autoclaved aerated concrete block, (b) concrete masonry unit, (c) 3D sandwich panel wall, and (d) pressed reeds panel. 


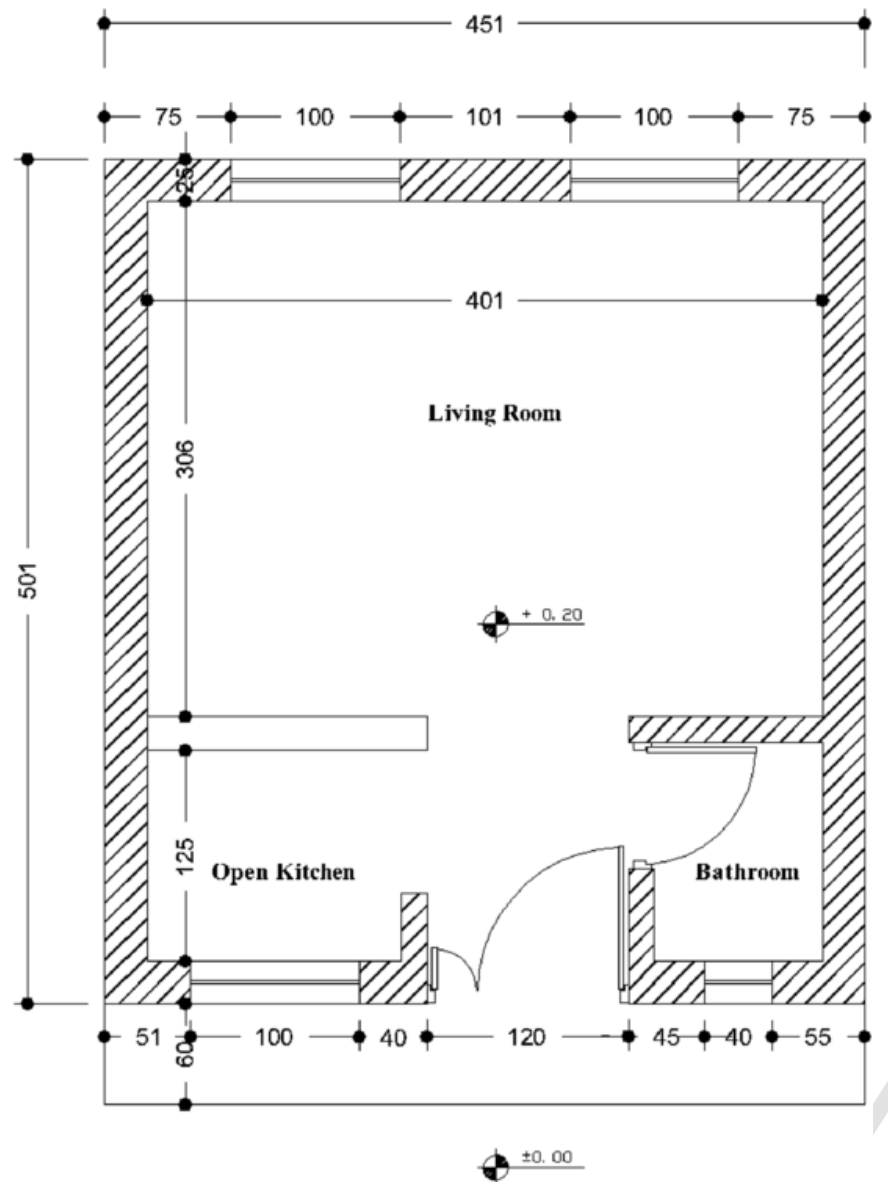

Fig. 2. Plan of a temporary housing unit (THU) (20- $\mathrm{m}^{2}$ type) constructed in Bam after the 2003 earthquake.

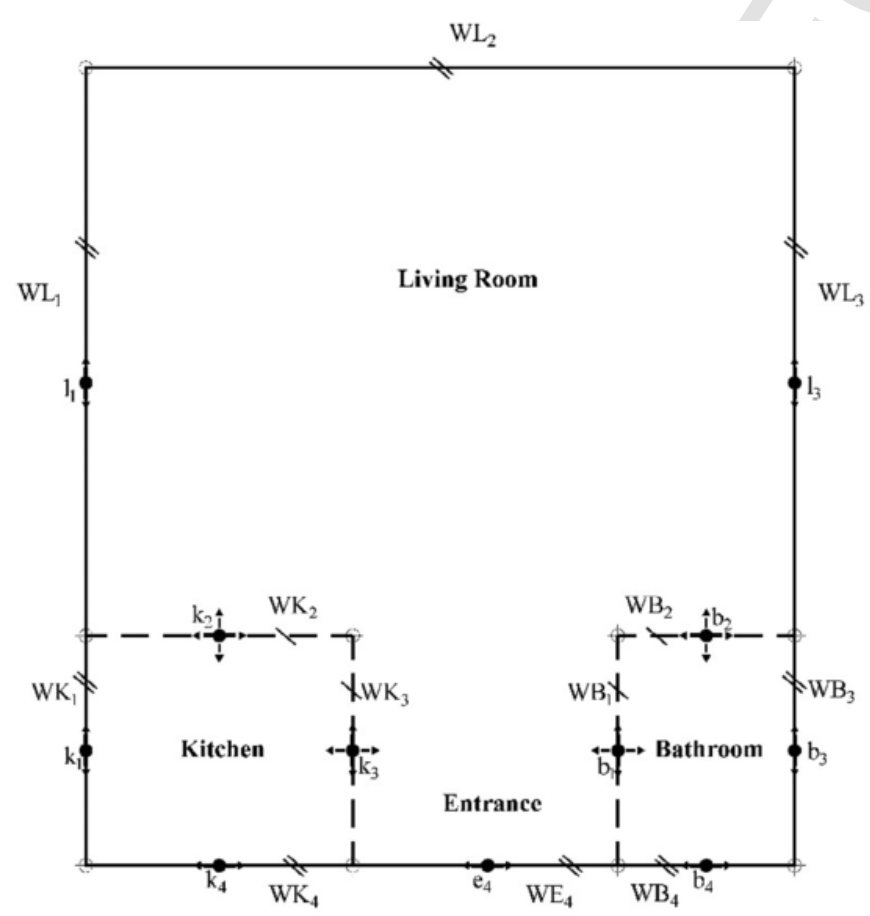

Fig. 3. Simple plan layout of the THU, including sliding walls, directions, and dependent walls.
UNHCR [60] considered that the minimum space in an emergency shelter for each person in tropical and warm climate conditions is $3.5 \mathrm{~m}^{2}$ per person, excluding the kitchen area. The area of this space should be $4.5 \mathrm{~m}^{2}-5.5 \mathrm{~m}^{2}$ per person in cold climate conditions or urban areas; however, this minimum space includes the kitchen. IFRC [61] applied the International Building Code (IBC) and Uniform Building Code (UBC) from the USA to determine the required areas. In this context, in addition to the Iranian National Building Code (INBC) as shown in Table 2, the building codes of the USA and UK were considered. Nevertheless, as IFRC [61] declared, these codes are oriented to permanent housing with a service life of 50 years, whilst the design life of TH is usually not considered to be longer than 5 years.

Additionally, areas of THUs are usually different from those of residential units. To this end, the information in Table 2 was normalised by considering the total area of the THU and standards for emergency sheltering. Likewise, it is worth noting that, according to the codes, the differences between THUs and residential units' interior sizes are primarily related to the living room, as this area also plays the role of a bedroom in the former.

For the second approach, 11 professors and researchers from both Shahid Beheshti University and Islamic Azad University (Tehran, Iran) and from the Polytechnic University of Catalonia (Barcelona, Spain) as well as two experts from the HFIR were interviewed. These interviews embraced the THUs interior areas and issues related to this research such as the general indexes, weights of indicators, and wide-ranging interior design problems of THUs.

By merging the results of both approaches, the ranges of variation of the wall lengths were established (Table 3 ) to fit the recommended aspect ratios assigned to each space. This assignment was carried out by including an indicator that considers the stakeholders' preferences (see Section 4.2.1).

Table 2

Minimum areas $\left(\mathrm{m}^{2}\right)$ of interior spaces for residential buildings.

\begin{tabular}{llllll}
\hline & Bedroom & Living Room & Kitchen & WC & References \\
\hline Iran & $6.50 \& 12.00^{\mathrm{a}}$ & $12.00^{\mathrm{a}}$ & 5.50 & 1.20 & {$[62]$} \\
USA & $6.50 \& 13.9^{\mathrm{b}}$ & $13.9 \& 20.4^{\mathrm{b}}$ & - & - & {$[63]$} \\
UK & $7.50 \& 11.50^{\mathrm{c}}$ & - & - & 1.60 & {$[64]$} \\
\hline
\end{tabular}

a The minimum area of the main living room and the main bedroom is $12 \mathrm{~m}^{2}$, and the minimum areas of the other living rooms and bedrooms are $6.50 \mathrm{~m}^{2}$.

b Each dwelling should have a room with an area of at least $13.9 \mathrm{~m}^{2}$.

c The minimum area of a single bedroom is $7.50 \mathrm{~m}^{2}$, and the minimum area of a double bedroom is $11.50 \mathrm{~m}^{2}$.

Table 3

Possible change ranges of walls considering the building codes and interview results.

\begin{tabular}{|c|c|c|c|c|c|}
\hline \multirow[t]{2}{*}{ Space } & \multirow[t]{2}{*}{ Partition } & \multirow[t]{2}{*}{ Type } & \multirow[t]{2}{*}{$\begin{array}{l}\text { Variable } \\
\text { Type }\end{array}$} & \multicolumn{2}{|c|}{$\begin{array}{l}\text { Change Range } \\
\text { (m) }\end{array}$} \\
\hline & & & & Min. & Max. \\
\hline \multirow[t]{3}{*}{ Living Room } & $\mathrm{WL}_{1}$ & Exterior & Continuous & -0.95 & 0.15 \\
\hline & $\mathrm{WL}_{2}$ & Exterior & Constant & 0.00 & 0.00 \\
\hline & $\mathrm{WL}_{3}$ & Exterior & Continuous & -0.95 & 0.30 \\
\hline \multirow[t]{2}{*}{ Kitchen } & $\begin{array}{l}\mathrm{WK}_{1} \& \\
\mathrm{WK}_{3}\end{array}$ & Exterior & Continuous & -0.15 & 0.95 \\
\hline & $\begin{array}{l}\mathrm{WK}_{2} \& \\
\mathrm{WK}_{4}\end{array}$ & Interior & Continuous & -0.30 & 0.50 \\
\hline \multirow[t]{2}{*}{ Bathroom } & $\begin{array}{l}\mathrm{WB}_{1} \& \\
\mathrm{WB}_{3}\end{array}$ & Exterior & Continuous & -0.3 & 0.95 \\
\hline & $\begin{array}{l}\mathrm{WB}_{2} \& \\
\mathrm{WB}_{4}\end{array}$ & Interior & Continuous & 0.00 & 0.50 \\
\hline Entrance & $\mathrm{WE}_{4}$ & Exterior & Continuous & -0.20 & 0.00 \\
\hline
\end{tabular}


As shown in Table 3, the dynamic design parameters are the dimensions of the sliding walls and floor areas of the four spaces, whereas the static parameters are the height, shape, roof, windows, and doors of the THUs. Table 4 illustrates a dependency matrix (one indicates dependency).

The second group of parameters considered in the sustainability analysis is related to the construction materials of the THU components (see Table 5). Some materials can be used in different components of the THU (e.g. the foundation and roof are the same for all possible solutions); these are noted as Constant in Table 5. Put another way, when the interior geometries are changed within the defined range, the amounts of these materials remain constant. However, other construction materials change, based on each floor plan's geometrical design. These are denoted Continuous variables in Table 5.

As shown in Table 5, the main continuous components are the exterior and interior walls and floors. When the walls are moved to explore the highest SI, the geometrical properties of the walls and floors are changed. In this context, all of the materials for the floors and two types of walls (interior and exterior) for the interior spaces of the THU are presented in Table 6.

\subsection{Integrated value model for sustainability assessment (MIVES)}

The MIVES method was selected as the approach for assessing the sustainability index (SI) of the plan layout alternatives for the THUs. The MIVES method, as a sustainability assessment approach, has already been used in other fields: (1) post-disaster housing management [ [27,55,65]]; (2) buildings structures [66]; (3) architectural active learning [67]; (4) school edifices [68]; (5) Spanish code of concrete structure [69]; (6) building facades [70]; (7) infrastructures [ [71,72]], and others.

The method consists of five steps: (1) designing a requirements tree, (2) specifying minimum $\left(X_{\min }\right)$ and maximum $\left(X_{\max }\right)$ satisfaction values for each indicator, (3) determining the tendency and shape of the value function, (4) weighting indicators and requirements $\left(\lambda_{i}\right)$ and, (5), summing partial satisfaction values $\left(V_{i}\right)$ to compute the SI by using the equation (1).

$S I=\sum \lambda_{i} . V_{i}\left(x_{i}\right)$

$V_{i}\left(x_{i}\right)$ : The value function of each indicator, criterion or requirement.

$\lambda_{i}$ : The weight of the indicator, criterion or requirement considered.

Equations (2) and (3) were used to obtain each indicator value. Equation (3) was applied to achieve factor $B$ for equation (2). Equation
(3) allows normalizing the indicators' values $\left(V_{i}\left(x_{i}\right)\right)$ between a range of zero and one.

$V_{i}=\mathrm{A}+\mathrm{B} \cdot\left[1-e^{-k_{i} \cdot\left(\frac{\left|X_{A l t_{i}}-X_{\min }\right|}{C_{i}}\right)^{P_{i}}}\right]$

$A$ : The response value $X_{\min }$ (indicator abscissa), generally $A=0$.

$X_{A l t_{i}}$ : The indicator abscissa that generates the value $V_{i}$

$P_{i}$ : A shape factor that determines whether the curve is concave or convex, linear or $\mathrm{S}$-shaped

$C_{i}$ : The factor that establishes the value of the abscissa for the inflexion point in curves with $\mathrm{Pi}>1$.

$K_{i}$ : The factor that defines the response value to $C_{i}$

$B$ : The factor preventing the function from leaving the range $(0.00$, 1.00); obtained with equation (3).

$B=\left[1-e^{k_{i} \cdot\left(\frac{\left|X_{\max }-X_{\min }\right|}{C_{i}}\right)^{P_{i}}}\right]^{-1}$

\subsubsection{Indicator definition}

According to the MIVES concept, a decision-making tree (DMT) should include the three pillars of sustainability (T), and those criteria and indicators representative to the case under analysis. The DMT for this research (Fig. 4) was determined based on the local stakeholders' preferences, as identified through seminars and an extensive literature review. The economic requirement $\left(\mathrm{R}_{1}\right)$ represents the investment required to implement a certain THU layout over its entire life cycle, with the capital investment $\left(\mathrm{C}_{1}\right)$ being the determining criterion. The social requirement $\left(\mathrm{R}_{2}\right)$ assesses the effect of each alternative on the DP, as the occupants of units, and third parties potentially affected or involved. The social requirement embraces four criteria: $\left(\mathrm{C}_{2}\right)$ delivery time, $\left(\mathrm{C}_{3}\right)$ comfort, $\left(\mathrm{C}_{4}\right)$ safety, and $\left(\mathrm{C}_{5}\right)$ DP preference. The environmental requirement $\left(R_{3}\right)$ considers the environmental impacts of the overall life cycles of the alternatives by means of $\left(\mathrm{C}_{6}\right)$ resource consumption and $\left(\mathrm{C}_{7}\right)$ emission criteria.

The capital investment $\left(\mathrm{C}_{1}\right)$ encompasses two indicators: the $\left(\mathrm{I}_{1}\right)$ construction cost of THU alternatives $\left(\operatorname{cost} / \mathrm{m}^{2}\right)$, and $\left(\mathrm{I}_{2}\right)$ maintenance cost of those expected repair activities during service. A second life use is assumed to have occurred for most of THUs in Bam. It is assumed that these units are re-used for the same function in the same location for a total extended life of fifty years. In this regard, the service lifespan of the THU and construction materials were determined from the White-

Table 4

Dependency matrix of the wall lengths.

\begin{tabular}{|c|c|c|c|c|c|c|c|c|c|c|c|c|}
\hline & \multicolumn{12}{|c|}{ Walls of Spaces } \\
\hline & $\mathrm{WL}_{1}$ & $\mathrm{WL}_{2}$ & $\mathrm{WL}_{3}$ & $\mathrm{WK}_{1}$ & $\mathrm{WK}_{2}$ & $\mathrm{WK}_{3}$ & $\mathrm{WK}_{4}$ & $\mathrm{WB}_{1}$ & $\mathrm{WB}_{2}$ & $\mathrm{WB}_{3}$ & $\mathrm{WB}_{4}$ & $\mathrm{WE}_{4}$ \\
\hline $\mathrm{WL}_{1}$ & 1 & 0 & 0 & 1 & 0 & 0 & 0 & 0 & 0 & 0 & 0 & 0 \\
\hline $\mathrm{WL}_{2}$ & 0 & 1 & 0 & 0 & 0 & 0 & 0 & 0 & 0 & 0 & 0 & 0 \\
\hline $\mathrm{WL}_{3}$ & 0 & 0 & 1 & 0 & 0 & 0 & 0 & 0 & 0 & 1 & 0 & 0 \\
\hline $\mathrm{WK}_{1}$ & 1 & 0 & 0 & 1 & 0 & 1 & 0 & 0 & 0 & 0 & 0 & 0 \\
\hline $\mathrm{WK}_{2}$ & 0 & 0 & 0 & 0 & 1 & 0 & 1 & 0 & 1 & 0 & 0 & 0 \\
\hline $\mathrm{WK}_{3}$ & 0 & 0 & 0 & 1 & 0 & 1 & 0 & 0 & 0 & 0 & 0 & 0 \\
\hline $\mathrm{WK}_{4}$ & 0 & 0 & 0 & 0 & 1 & 0 & 1 & 0 & 0 & 0 & 1 & 1 \\
\hline $\mathrm{WB}_{1}$ & 0 & 0 & 0 & 0 & 0 & 0 & 0 & 1 & 0 & 1 & 0 & 0 \\
\hline $\mathrm{WB}_{2}$ & 0 & 0 & 0 & 0 & 1 & 0 & 0 & 0 & 1 & 0 & 1 & 0 \\
\hline $\mathrm{WB}_{3}$ & 0 & 0 & 1 & 0 & 0 & 0 & 0 & 1 & 0 & 1 & 0 & 0 \\
\hline $\mathrm{WB}_{4}$ & 0 & 0 & 0 & 0 & 0 & 0 & 1 & 0 & 1 & 0 & 1 & 1 \\
\hline $\mathrm{WE}_{4}$ & 0 & 0 & 0 & 0 & 0 & 0 & 1 & 0 & 0 & 0 & 1 & 1 \\
\hline
\end{tabular}


Table 5

Main components and construction materials for the temporary housing unit (THU).

\begin{tabular}{|c|c|c|}
\hline Component & Material & $\begin{array}{l}\text { Variable } \\
\text { Type }\end{array}$ \\
\hline $\begin{array}{l}\text { Wall/Partition } \\
\text { (Exterior \& } \\
\text { Interior) }\end{array}$ & $\begin{array}{l}\text { Concert Masonry Units }\left(0.40 \cdot 0.20 \cdot 0.30 \mathrm{~m}^{3} \&\right. \\
\left.0.40 \cdot 0.10 \cdot 0.20 \mathrm{~m}^{3}\right)\end{array}$ & Continuous \\
\hline $\begin{array}{l}\text { Wall/Partition } \\
\text { (Finishing) }\end{array}$ & $\begin{array}{l}\text { Tile (in), Cement Plaster (out), Gypsum } \\
\text { Plaster (in) }\end{array}$ & Continuous \\
\hline Floor & $\begin{array}{l}\text { lean concrete } 150 \mathrm{~kg} / \mathrm{m}^{3} \text {, the thickness is } \\
0.15 \mathrm{~m} \text { and Iranian mosaic tile }\end{array}$ & Continuous \\
\hline Roof & $\begin{array}{l}\text { Corrugated galvanized iron with } 4 \mathrm{~cm} \text { of } \\
\text { polystyrene }\end{array}$ & Constant \\
\hline Foundation & $\begin{array}{l}\text { Strap footing foundation, the height is } 0.35 \\
\mathrm{~m}\end{array}$ & Constant \\
\hline Structure & Steel hollow square section & Constant \\
\hline Footing (Plinth) & Brick or block, the height is $0.20 \mathrm{~m}$ & Constant \\
\hline Window & $\begin{array}{l}\text { Metal window, the dimension is, type I: } \\
1.00 \cdot 1.00 \mathrm{~m}^{2} \text { and type II: } 0.50 \cdot 0.30 \mathrm{~m}^{2}\end{array}$ & Constant \\
\hline Door & Metal door, the dimension is $2.00 \cdot 1.00 \mathrm{~m}^{2}$ & Constant \\
\hline Mortar & Cement mortar 1:6 & Continuous \\
\hline
\end{tabular}

Table 6

Construction materials for the interior spaces of the THU.

\begin{tabular}{|c|c|c|c|}
\hline \multirow[t]{2}{*}{ Space } & \multicolumn{2}{|l|}{ Wall/Partition } & \multirow[t]{2}{*}{ Floor } \\
\hline & Type I (Exterior) & Type II (Interior) & \\
\hline $\begin{array}{l}\text { Living } \\
\text { Room }\end{array}$ & $\begin{array}{l}\text { - Concrete ma- } \\
\text { sonry block } \\
\text { - Cement mortar } \\
\text { 1:6 } \\
\text { - Cement plaster } \\
\text { 1:3-1:2 } \\
\text { - Gypsum-sand } \\
\text { plaster }\end{array}$ & - & $\begin{array}{l}\text { - Lean concrete } \\
150 \mathrm{~kg} / \mathrm{m}^{3} \\
\text { - Iranian mosaic } \\
\text { tile } \\
\text { - Cement mortar } \\
1: 6\end{array}$ \\
\hline Kitchen & $\begin{array}{l}\text { - Concrete ma- } \\
\text { sonry block } \\
\text { - Cement mortar } \\
\text { 1:6 } \\
\text { - Cement plaster } \\
\text { 1:3-1:2 } \\
\text { - Tile }\end{array}$ & $\begin{array}{l}\text { - Concrete ma- } \\
\text { sonry block } \\
\text { - Cement mortar } \\
\text { 1:6 } \\
\text { - Tile } \\
\text { - Gypsum-sand } \\
\text { plaster } \\
\text { - Insulation }\end{array}$ & $\begin{array}{l}\text { - Lean concrete } \\
150 \mathrm{~kg} / \mathrm{m}^{3} \\
\text { - Ceramic tile } \\
\text { flooring } \\
\text { - Cement mortar } \\
1: 6 \\
\text { - Insulation }\end{array}$ \\
\hline Bathroom & $\begin{array}{l}\text { - Concrete ma- } \\
\text { sonry block } \\
\text { - Cement mortar } \\
\text { 1:6 } \\
\text { - Cement plaster } \\
\text { 1:3-1:2 } \\
\text { - Tile }\end{array}$ & $\begin{array}{l}\text { - Concrete ma- } \\
\text { sonry block } \\
\text { - Cement mortar } \\
\text { 1:6 } \\
\text { - Tile } \\
\text { - Gypsum-sand } \\
\text { plaster } \\
\text { - Insulation }\end{array}$ & $\begin{array}{l}\text { - Lean concrete } \\
150 \mathrm{~kg} / \mathrm{m}^{3} \\
\text { - Ceramic tile } \\
\text { flooring } \\
\text { - Cement mortar } \\
1: 6 \\
\text { - Insulation }\end{array}$ \\
\hline Entrance & $\begin{array}{l}\text { - Concrete ma- } \\
\text { sonry block } \\
\text { - Cement mortar } \\
\text { 1:6 } \\
\text { - Cement plaster } \\
\text { 1:3-1:2 } \\
\text { - Gypsum-sand } \\
\text { plaster }\end{array}$ & - & $\begin{array}{l}\text { - Lean concrete } \\
150 \mathrm{~kg} / \mathrm{m}^{3} \\
\text { - Iranian mosaic } \\
\text { tile } \\
\text { - Cement mortar } \\
\text { 1:6 }\end{array}$ \\
\hline
\end{tabular}

stone facility maintenance and repair cost reference 2010-2011 [73] and the Iranian pricing schedule of building 2004 [74]. Additionally, the lifespans of the materials used in the THU are assessed from other sources as well, as shown in Table 7.

The delivery time $\left(\mathrm{C}_{2}\right)$ includes the construction time $\left(\mathrm{I}_{3}\right)$ which accounts for the required person-hours for construction; this is quantified based upon the activity type and its amount. Material off-cuts (e.g., mosaics), which could have an impact on the total time, were neglected because they had a minor influence in the case study. Other factors that could have impacts on the delivery time (ex., construction materials availably) were disregarded since those were included in the construction cost indicator.

Comfort $\left(\mathrm{C}_{3}\right)$ comprises two indicators: $\left(\mathrm{I}_{4}\right)$ thermal comfort, which assesses the required thermal transmittances of alternative layouts, and ( $\left.I_{5}\right)$ noise pollution, which considers the environmental noise owing to alternative units. The noise pollution indicator could include two issues: (1) impacts of harmful sounds that have been generated owing to construction activities during the construction phase on labourers and the host area; and (2) the acoustic comfort levels of alternative units for the DP, as occupants, during the operation phase. However, the former was found to be negligible, as the installation of THU units does not require the use of heavy trucks or cranes, or concrete vibrators or soil pneumatic compressors for soil compaction. In this regard, it must be emphasised that the site is considered ready for construction and, hence, the preparation phase is out of the scope of this analysis. Therefore, the acoustic comfort during the operation phase is to be assessed. For this purpose, the acceptable ranges of thermal resistance and acoustics were established from the technical literature (Table 8).

The safety $\left(\mathrm{C}_{4}\right)$ is meant to assess the occupants' security and safety levels, and includes the indicator fire resistance $\left(\mathrm{I}_{6}\right)$. Accepted technical codes are used for determining fire-resistance ratings (Table 8).

The criterion DP preference $\left(\mathrm{C}_{5}\right)$ includes the indicator DP preference $\left(\mathrm{I}_{7}\right)$ that represents the satisfaction of the DP in terms of usability and adequacy to the users' expectations, including cultural traditions. These items are directly related to the interior geometrical design and spatial distribution. Two approaches were followed to quantify this indicator: (1) questionnaires and interviews; and (2) minimum required areas of interior spaces according to standards (refer to section 4 and Table 2).

To identify the DP preferential factors, 32 interviews were conducted. As the Bam DP from several years ago is inaccessible, the authors interviewed the DP from the earthquake that occurred in 2017 at Kermanshah (western province of Iran). The interview concerned the required interior spaces, the associated areas, and the relative importance (weights) of each interior space. A total of 32 families accommodated in THUs since the aftermath of the earthquake were interviewed. A representative majority of the interviewed people complained regarding sharing restrooms with others, outside of their units. These families preferred a larger living room, divisible into two spaces, to separate private areas for parents and children.

To guarantee a higher statistical representation of the population, an online questionnaire was randomly sent to more than 500 people via a social media application, which is popular in Iran. Through this approach, 181 reliable responses were received. The questionnaire was designed to include two sections: first, the relative importance of each space in the THU was specified and, second, the area assigned to each space among five different area distribution sets was chosen (Table 9). For the first section, $88.9 \%$ of respondents ordered (from high to low importance) the internal spaces as: living room, bathroom, and kitchen.

The resources consumption $\left(\mathrm{C}_{6}\right)$ criterion is aimed at quantifying the natural resources consumed, by means of two indicators. The energy consumption $\left(\mathrm{I}_{8}\right)$ indicator concerns the manufacturing, construction, and demolition phases. The Inventory of Carbon \& Energy (ICE) [84] is also considered as a database. In contrast to most environmental impact analyses on buildings, the energy consumption through the operational phase was not considered in this study case, as $\left(\mathrm{I}_{4}\right)$ thermal comfort is a representative indicator for energy consumption during the operation phase.

Waste material $\left(\mathrm{I}_{9}\right)$ generated in the manufacturing, construction, and demolition phases. Both waste and management aspects are assessed in this indicator. For this purpose, after a thorough literature review was conducted, scarce data on waste material ratios were found. This can be owing to the diverse points of view from which the analyses were performed and the variety of building technologies that 


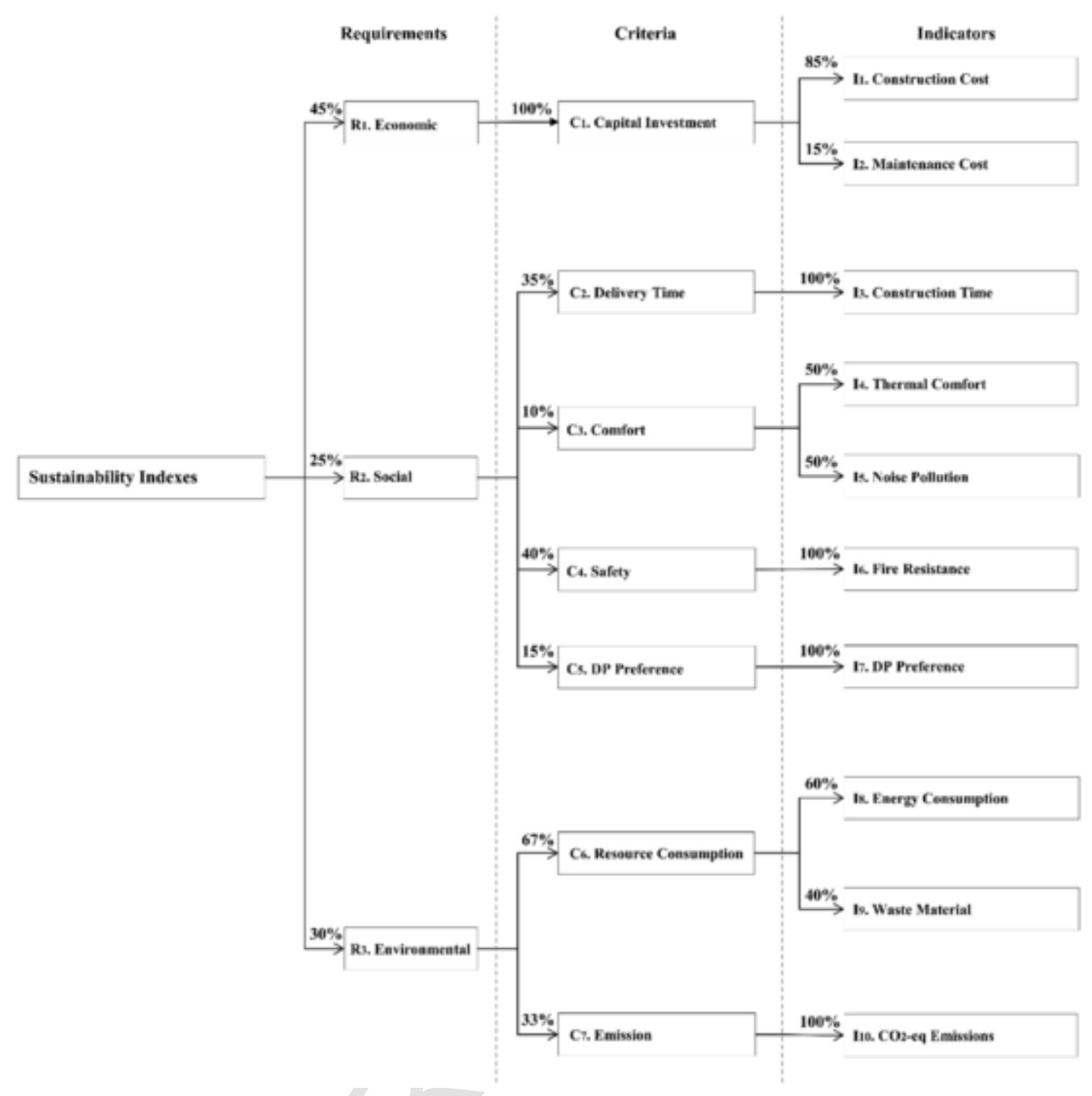

Fig. 4. Requirements tree designed for this model.

Table 7

Lifespan of the THU materials.

\begin{tabular}{lll}
\hline Material & \multicolumn{2}{l}{ Lifespan (year) } \\
\hline & Abate et al. (2009) [75], & Cochran (2006) [76], $^{\mathrm{d}}$ \\
\hline Concrete masonry block & $100^{\mathrm{b}}$ & $75^{\mathrm{e}}$ \\
Tile & 75 & 20 \\
Ceramic tile flooring & 50 & 20 \\
Mosaic tile (Terrazzo) & 75 & - \\
Cement mortar & - & $75^{\mathrm{f}}$ \\
Cement plaster & $75^{\mathrm{c}}$ & $75^{\mathrm{f}}$ \\
Gypsum-sand plaster & $75^{\mathrm{c}}$ & - \\
Insulation & - & - \\
\hline
\end{tabular}

${ }^{\text {a }}$ Frequency of replacing material time are mentioned.

b The exterior wall is considered. Frequency of replacing a concrete block of the interior wall is 75 years.

c General Plaster (interior)

d Typical.

e Brick.

f Masonry cement. were analysed, both aspects leading to data with high variability (see Table 10). The material waste percentages reported in Ref. [74] during the construction phase were considered for this case study.

Additionally, both material reuse and recycling potentials were quantified according to Refs. [ [93,94]], Table 11, to assess the waste management rate.

The emission $\left(\mathrm{C}_{7}\right)$ criterion is represented by the indicator $\mathrm{CO}_{2}$-eq emissions $\left(\mathrm{I}_{10}\right)$ to quantify the total equivalent $\mathrm{CO}_{2}$ emissions during the life cycle assessment (LCA). This embraces all greenhouse gases (GHGs) owing to the manufacturing, construction, and demolition phases. The Inventory of Carbon and Energy (ICE) [84] was considered as the reference database for quantifying this indicator.

It should be emphasised that the indicators were identified and determined based upon an extensive literature review (Table 12). Furthermore, although the indicator categorizations were mentioned above, these indicators could have been assigned to other requirement groups simultaneously with regard to their impacts. In other words, there are many interactions between indicators. However, according to the concept of the MIVES method, each indicator is normally considered based on one of its main impacts. The main factors of each are listed in Table 12 . 
Table 8

Exterior wall standards for residential buildings.

\begin{tabular}{|c|c|c|c|c|}
\hline \multirow[b]{2}{*}{ Acoustic range } & \multicolumn{3}{|c|}{ Exterior wall standards } & \multirow{2}{*}{$\begin{array}{c}\text { References } \\
{[77]}\end{array}$} \\
\hline & Iran & & $\begin{array}{l}\text { Bedroom: } \\
R_{w}>45 ; \\
\text { Living } \\
\text { room: } R_{w} \\
>40 \\
\text { Kitchen: } R_{w} \\
>35\end{array}$ & \\
\hline & USA & & $\begin{array}{l}\text { Grade } \\
1: \text { STC }>55 ; \\
\text { Grade } \\
2: \text { STC }>52 ; \\
\text { Grade } \\
3: \text { STC }>48 \\
\text { (general } \\
\text { STC }>50 \text { ) }\end{array}$ & [78] \\
\hline & UK & & $\begin{array}{l}D_{n T, w}+C_{t r} \\
>45\end{array}$ & [79] \\
\hline & Germ & ly* & $\begin{array}{l}\text { Class A: } R_{w} \\
>68 ; \text { Class } \\
\text { B: } R_{w}>63 ; \\
\text { Class C: } R_{w}^{\prime} \\
>57\end{array}$ & [78] \\
\hline \multirow[t]{2}{*}{ Fire resistance (h) } & Iran & & 1 & [80] \\
\hline & USA & & 1 & [81] \\
\hline \multirow[t]{3}{*}{ Thermal Resistance } & $\begin{array}{l}\text { Iran } \\
* *\end{array}$ & Light & $\begin{array}{l}\text { Group 1: } \\
R>2.8 ; \\
\text { Group 2: } \\
R>2.1 ; \\
\text { Group 3: } \\
R>1.5\end{array}$ & [82] \\
\hline & & Heavy & $\begin{array}{l}\text { Group 1: } \\
R>1.9 \\
\text { Group 2: } \\
R>1.4 ; \\
\text { Group 3: } \\
R>1.0\end{array}$ & \\
\hline & UK & & $\begin{array}{l}U \text {-value: } \\
0.3-0.4\end{array}$ & [83] \\
\hline
\end{tabular}

* Row housing.

** Light wall: surface mass $<150 \mathrm{~kg} / \mathrm{m} .{ }^{2}$.

** Heavy wall: surface mass $>150 \mathrm{~kg} / \mathrm{m} .{ }^{2}$.

$\mathrm{R}_{\mathrm{w}}^{\prime}$ : Weighted sound reduction index $(\mathrm{dB}) ; \mathrm{D}_{\mathrm{nT}, \mathrm{w}}+\mathrm{C}_{\mathrm{tr}}$ : Airborne sound insulation $(\mathrm{dB}) ; R$ : Thermal resistance $\left(\mathrm{m}^{2} . \mathrm{K} / \mathrm{W}\right)$.

Table 9

Chosen areas of the three spaces by participants.

\begin{tabular}{llll}
\hline Participants (\%) & Area $\left(\mathrm{m}^{2}\right)$ & & \\
\hline & Living Room & Kitchen & Bathroom \\
\hline 47.3 & 14 & 3 & 3 \\
42.1 & 12 & 5 & 2 \\
10.6 & Other & & \\
\hline
\end{tabular}

Nevertheless, the different impacts of each indicator are considered in Table 12. Several impacts of each indicator could assist experts and decision makers in assigning a more appropriate weight to each index. In other words, the importance (weights) of the indexes are specified easily and accurately by considering the influential groups of indicators, as shown in Table 12 .

\subsubsection{Determination of the model's parameters}

After defining the DMT (Fig. 4), the parameters for evaluating the values (satisfaction) generated by each indicator were determined. In this step, according to Alarcon et al. [120], the tendency (increase or decrease) and the shape (convex, concave, linear, and S-shaped) of
Table 10

Percentage of waste material during the construction phase and recycling.

\begin{tabular}{|c|c|c|c|c|c|c|}
\hline \multirow[t]{2}{*}{ Material } & \multicolumn{5}{|c|}{ Waste (\%) } & \multirow{2}{*}{$\begin{array}{l}\text { Recycling } \\
\text { Potential }\end{array}$} \\
\hline & $\begin{array}{l}\text { Solís- } \\
\text { Guzmán } \\
\text { et al. } \\
\text { [85], }\end{array}$ & $\begin{array}{l}\text { Prairie } \\
\text { Village } \\
{[86]}\end{array}$ & $\begin{array}{l}\text { Asgari } \\
\text { et al. } \\
\underset{\mathrm{e}}{[87]} \text {, }\end{array}$ & $\begin{array}{l}\text { Schuette } \\
\text { \& Liska } \\
{[88],{ }^{\mathrm{f}}}\end{array}$ & $\begin{array}{l}\text { Pinto \& } \\
\text { Agopyan } \\
\text { [89], }\end{array}$ & \\
\hline $\begin{array}{l}\text { Concrete } \\
\text { masonry } \\
\text { block }\end{array}$ & $\begin{array}{l}2.13 \& \\
5.78{ }^{a}\end{array}$ & $0.61^{d}$ & 18 & 3.5 & - & - \\
\hline Tile & 2.55 & 1.24 & 4.80 & 6.5 & 9 & Landfill \\
\hline $\begin{array}{l}\text { Ceramic } \\
\text { tile } \\
\text { flooring }\end{array}$ & $0.25^{\mathrm{b}}$ & 1.24 & 4.80 & - & 7 & Landfill \\
\hline $\begin{array}{l}\text { Mosaic } \\
\text { tile } \\
\text { (Terrazzo) }\end{array}$ & $0.25^{\mathrm{b}}$ & & 5 & - & - & Landfill \\
\hline $\begin{array}{l}\text { Cement } \\
\text { mortar }\end{array}$ & - & & - & 3.5 & 46 & Landfill \\
\hline $\begin{array}{l}\text { Cement } \\
\text { plaster }\end{array}$ & $0.33^{c}$ & - & - & - & - & Landfill \\
\hline $\begin{array}{l}\text { Gypsum- } \\
\text { sand } \\
\text { plaster }\end{array}$ & $0.33^{c}$ & - & 4.20 & - & - & Landfill \\
\hline
\end{tabular}

a Brick exterior and interior walls, respectively.

b Floor.

c General Plaster.

d Cinder block.

e Construction and demolition waste.

f Cited by Chen et al. [91].

g Cited by Bossink \& Brouwers [92].

Table 11

Reuse and recycle potential of materials used in the THU.

\begin{tabular}{|c|c|c|c|}
\hline \multirow[t]{2}{*}{ Material } & \multicolumn{3}{|l|}{ Viability } \\
\hline & $\begin{array}{l}\text { Reuse in } \\
\text { Situ }\end{array}$ & $\begin{array}{l}\text { Reclaimed } \\
\text { Material }\end{array}$ & $\begin{array}{l}\text { Recycled-Content Building } \\
\text { Product }\end{array}$ \\
\hline $\begin{array}{l}\text { Concrete masonry } \\
\text { block }\end{array}$ & High & Low & High \\
\hline Tile & High & High & Medium \\
\hline Ceramic tile flooring & Low & Low & Medium \\
\hline Mosaic tile (Terrazzo) & - & - & - \\
\hline Cement mortar & - & - & - \\
\hline Cement plaster & Medium & - & - \\
\hline Gypsum-sand plaster & Medium & - & - \\
\hline $\begin{array}{l}\text { Waterproofing } \\
\text { flexible sheets }\end{array}$ & Medium & Low & Medium \\
\hline
\end{tabular}

Source: Addis (2012) [94].

the value function of each indicator (see Fig. 5) were assigned. According to Alarcon et al. [120], a concave-shaped function is used when satisfaction decreases slightly or increases quickly. When the satisfaction tendency is contrary to the concave curve, a convex-shaped function is the most suitable. A linear function is applied when there is a steadily increasing/decreasing satisfaction. If the satisfaction tendency embraces a combination of convex and concave functions simultaneously, an $S$-shaped function is the most representative.

The constitutive parameters of the value functions (Equation (2) and (3)) are presented in Table 13. These parameters, including both tendency and shape, were established based upon the scientific literature, Iranian and International Building Codes, and the background of experts (including professors and HFIR practitioners who attended the seminars, see Table 13). 
Table 12

Main factors and impacts of the indicators.

\begin{tabular}{|c|c|c|c|}
\hline Indicator & $\begin{array}{l}\text { Factor (Sub- } \\
\text { indicator) }\end{array}$ & Impact & References \\
\hline $\mathrm{I}_{1}$. Construction Cost & $\begin{array}{l}\text { - Re- } \\
\text { sources } \\
\text { (Mater- } \\
\text { ial, En- } \\
\text { ergy, } \\
\text { Water) } \\
\text { - Design } \\
\text { - Labor } \\
\text { - Hazard } \\
\text { - Location } \\
\text { (Site, In- } \\
\text { frastruc- } \\
\text { ture, } \\
\text { Weather) }\end{array}$ & $\begin{array}{l}\text { - In- } \\
\text { vestors }\end{array}$ & [95-97] \\
\hline $\mathrm{I}_{2}$. Maintenance Cost & $\begin{array}{l}\text { - Lifespan } \\
\text { of Mater- } \\
\text { ial } \\
\text { - Building } \\
\text { Charac- } \\
\text { teristics } \\
\text { - Owner- } \\
\text { ship Fea- } \\
\text { tures }\end{array}$ & $\begin{array}{l}\text { - In- } \\
\text { vestors } \\
\text { - Occu- } \\
\text { pants }\end{array}$ & {$[98,99]$} \\
\hline $\mathrm{I}_{3}$. Construction Time & $\begin{array}{l}\text { Project } \\
\text { (type, } \\
\text { Charac- } \\
\text { teristics, } \\
\text { Volume, } \\
\text { Design, } \\
\text { Location, } \\
\text { Technol- } \\
\text { ogy, } \\
\text { etc.) } \\
\text { - Owner } \\
\text { - Contrac- } \\
\text { tor } \\
\text { - Consul- } \\
\text { tant } \\
\text { Material } \\
\text { - Labour } \\
\text { Others } \\
\text { (such as } \\
\text { Uncer- } \\
\text { tainties, } \\
\text { Unpre- } \\
\text { dictable } \\
\text { Condi- } \\
\text { tions, } \\
\text { Regula- } \\
\text { tions, } \\
\text { etc.) }\end{array}$ & $\begin{array}{l}\text { Occu- } \\
\text { pants' } \\
\text { Satis- } \\
\text { fac- } \\
\text { tions } \\
\text { - Con- } \\
\text { struc- } \\
\text { tion } \\
\text { Cost }\end{array}$ & [100-103] \\
\hline
\end{tabular}

Table 12 (Continued)

\begin{tabular}{|c|c|c|c|}
\hline Indicator & $\begin{array}{l}\text { Factor (Sub- } \\
\text { indicator) }\end{array}$ & Impact & References \\
\hline $\mathrm{I}_{4}$. Thermal Comfort & $\begin{array}{l}\text { - Occu- } \\
\text { pants' } \\
\text { Behav- } \\
\text { ioural } \\
\text { Adjust- } \\
\text { ments } \\
\text { - Building } \\
\text { Features } \\
\text { - Climate } \\
\text { Condi- } \\
\text { tions } \\
\end{array}$ & $\begin{array}{l}\text { - Occu- } \\
\text { pants' } \\
\text { Com- } \\
\text { fort } \\
\text { - En- } \\
\text { ergy } \\
\text { Con- } \\
\text { sump- } \\
\text { tion } \\
\text { - } \mathrm{CO}_{2} \\
\text { Emis- } \\
\text { sion } \\
\text { - Opera- } \\
\text { tion } \\
\text { Cost }\end{array}$ & [104-106] \\
\hline$I_{5}$. Noise Pollution & $\begin{array}{l}\text { - Con- } \\
\text { struc- } \\
\text { tion } \\
\text { Noise } \\
\text { - Acoustic } \\
\text { Perfor- } \\
\text { mance }\end{array}$ & $\begin{array}{l}\text { - Occu- } \\
\text { pants' } \\
\text { Com- } \\
\text { fort } \\
\text { - Occu- } \\
\text { pa- } \\
\text { tional } \\
\text { Distur- } \\
\text { bance } \\
\text { - Envi- } \\
\text { ron- } \\
\text { mental } \\
\text { Nega- } \\
\text { tively }\end{array}$ & [107-110] \\
\hline $\mathrm{I}_{6}$. Fire Resistance & $\begin{array}{l}\text { - Building } \\
\text { Fire Re- } \\
\text { sponse } \\
\text { Perfor- } \\
\text { mance } \\
\text { - Occu- } \\
\text { pants' } \\
\text { Re- } \\
\text { sponse } \\
\text { - Escape } \\
\text { Route }\end{array}$ & $\begin{array}{l}\text { - Occu- } \\
\text { pants' } \\
\text { Safety } \\
\text { - In- } \\
\text { vestors } \\
\text { - Envi- } \\
\text { ron- } \\
\text { mental } \\
\text { Nega- } \\
\text { tively }\end{array}$ & [111] \\
\hline I7. DP Preference & $\begin{array}{l}\text { Users } \\
\text { Prefer- } \\
\text { ence } \\
\text { De- } \\
\text { signer } \\
\text { (Archi- } \\
\text { tect) } \\
\text { Prefer- } \\
\text { ence } \\
\text { - Building } \\
\text { Stan- } \\
\text { dard }\end{array}$ & $\begin{array}{l}\text { - Occu- } \\
\text { pants' } \\
\text { Com- } \\
\text { fort } \\
\text { - Con- } \\
\text { struc- } \\
\text { tion } \\
\text { Cost } \\
\text { - Con- } \\
\text { struc- } \\
\text { tion } \\
\text { Time } \\
\text { - Envi- } \\
\text { ron- } \\
\text { mental } \\
\text { Nega- } \\
\text { tively }\end{array}$ & {$[25,112]$} \\
\hline
\end{tabular}


Table 12 (Continued)

\begin{tabular}{|c|c|c|c|}
\hline Indicator & $\begin{array}{l}\text { Factor (Sub- } \\
\text { indicator) }\end{array}$ & Impact & References \\
\hline I $_{8}$ Energy Consumption & $\begin{array}{l}\text { - Size \& } \\
\text { Loca- } \\
\text { tion } \\
\text { - Mater- } \\
\text { ial } \\
\text { - Archi- } \\
\text { tec- } \\
\text { tural } \\
\text { and } \\
\text { Struc- } \\
\text { tural } \\
\text { Design } \\
\text { - Build- } \\
\text { ing } \\
\text { Ser- } \\
\text { vices } \\
\text { (HVAC, } \\
\text { etc.) } \\
\text { - Occu- } \\
\text { pants' } \\
\text { Behav- } \\
\text { ioural }\end{array}$ & $\begin{array}{l}\text { - Envi- } \\
\text { ron- } \\
\text { men- } \\
\text { tal } \\
\text { Nega- } \\
\text { tively } \\
\text { - Con- } \\
\text { struc- } \\
\text { tion } \\
\text { Cost } \\
\text { - Oper- } \\
\text { ation } \\
\text { Cost }\end{array}$ & [113-115] \\
\hline I9. Waste Material & $\begin{array}{l}\text { - Design } \\
\text { - Pro- } \\
\text { cure- } \\
\text { ment } \\
\text { - Materi- } \\
\text { als } \\
\text { Han- } \\
\text { dling } \\
\text { - Opera- } \\
\text { tion } \\
\text { - Lifes- } \\
\text { pan of } \\
\text { Mater- } \\
\text { ial } \\
\text { - Reuse } \\
\text { \& Re- } \\
\text { cycle } \\
\text { Poten- } \\
\text { tial }\end{array}$ & $\begin{array}{l}\text { Envi- } \\
\text { ron- } \\
\text { men- } \\
\text { tal } \\
\text { Nega- } \\
\text { tively } \\
\text { - Con- } \\
\text { struc- } \\
\text { tion } \\
\text { Cost }\end{array}$ & {$[91,116,117]$} \\
\hline $\mathrm{I}_{10} \cdot \mathrm{CO}_{2}$-eq Emissions & $\begin{array}{l}\text { Manu- } \\
\text { factur- } \\
\text { ing } \\
\text { Mater- } \\
\text { ial } \\
\text { - Mater- } \\
\text { ial } \\
\text { Trans- } \\
\text { porta- } \\
\text { tion } \\
\text { Energy } \\
\text { Con- } \\
\text { sump- } \\
\text { tion } \\
\text { (Con- } \\
\text { struc- } \\
\text { tion } \\
\text { Activi- } \\
\text { ties \& } \\
\text { Occu- } \\
\text { pants } \\
\text { Activi- } \\
\text { ties) }\end{array}$ & $\begin{array}{l}\text { Envi- } \\
\text { ron- } \\
\text { men- } \\
\text { tal } \\
\text { Nega- } \\
\text { tively } \\
\text { - Peo- } \\
\text { ple's } \\
\text { Safety } \\
\end{array}$ & {$[118,119]$} \\
\hline
\end{tabular}

The weights (see Fig. 4) were assigned based upon the results of a seminar with 11 multidisciplinary experts: professors and researchers from architecture and civil engineering faculties of Iranian universities (Shahid Beheshti and Islamic Azad), from the Polytechnic University of Catalonia (UPC), Barcelona (Spain), and two experts from HFIR. The weighting process followed the well-known analytical hierarchy process (AHP) [125].

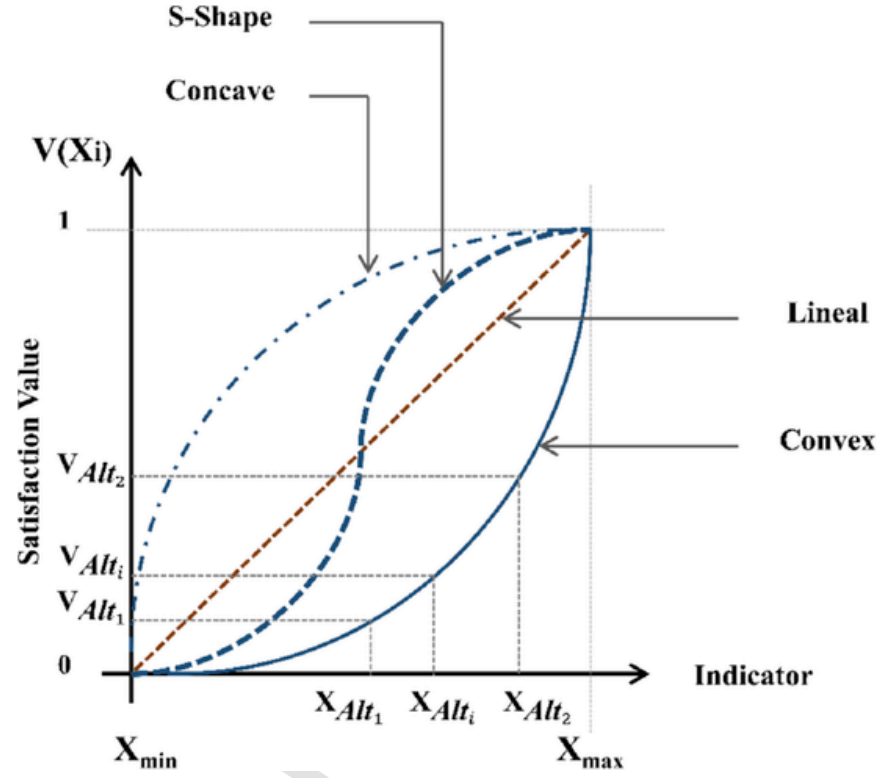

Fig. 5. Value function types, including convex, concave, linear, and S-shaped.

\subsection{Optimization model}

Both the designed MIVES-based model and the backtracking algorithm were implemented in $\mathrm{C}^{++}$. The input data includes three different groups:

1. Geometry parameters related to the floor plan design of units. In this case, nodes of spaces, which define edges and consequently boundaries, dimensions, and positions of doors and windows, possible variations of the sliding walls, and dependent/independent parameters belong to this data group (see Section 4.1).

2. Material parameters used for each THU alternative. Once a specific geometry is defined, the amount of materials is quantified, and the properties are transferred to the sustainability assessment model.

3. MIVES parameters (Fig. 4 and Table 13) required to assess the SI of each alternative.

In general, the optimization model, which operates based on a binary search approach, starts by reading the input data. The first step is to calculate the SI of the initial layout (that used in the case study of Bam, with SI = 0.54). From this, the algorithm generates variations and dependencies (new solutions), and both the areas (walls and spaces) and the amounts of required materials for each solution are computed. The areas of components are estimated with the shoelace algorithm. Finally, the SI of each alternative is assessed with the implemented MIVES model.

The algorithm progresses and generates further alternatives by modifying the dimensions and positions of the walls (restricted to compatible variations and dependency conditions). Then, the aforementioned steps are repeated. This loop is repeated until a layout with the maximum SI is determined. However, this research study applies a methodology based on the backtracking algorithm, in which the DMT is created by using the binary search approach to minimise the design exploration space. Walls are allowed to slide $0.05 \mathrm{~m}$ during the iterative process. By this assumption, the number of compatible solutions is greater than 77,000 . Nevertheless, the proposed scheme achieves the optimal solution in less than 131 iterations. 
Table 13

Parameters and coefficients for each indicator value function.

\begin{tabular}{|c|c|c|c|c|c|c|c|c|}
\hline Indicator & Unit & $\mathrm{Xmax}$ & $X \min$ & $\mathrm{C}$ & $\mathrm{K}$ & $\mathrm{P}$ & Shape & References \\
\hline $\mathrm{I}_{1}$ & IRR. & $5.4 \cdot 10^{6}$ & $3.5 \cdot 10^{6}$ & $1.2 \cdot 10^{6}$ & 0.100 & 2.00 & DCx & {$[74,121]$} \\
\hline $\mathrm{I}_{2}$ & IRR. & $5.2 \cdot 10^{5}$ & $2.8 \cdot 10^{5}$ & $1.4 \cdot 10^{5}$ & 0.01 & 1.50 & DCx & {$[73,74]$} \\
\hline $\mathrm{I}_{3}$ & Man-hour & $2.25 \cdot 10^{2}$ & $1.8 \cdot 10^{2}$ & $1.2 \cdot 10^{2}$ & $3.8 \cdot 10^{2}$ & 3.50 & DS & [74] \\
\hline $\mathrm{I}_{4}$ & $\left(\mathrm{~W} / \mathrm{m}^{2} \cdot \mathrm{K}\right)$ & 2.35 & 2.28 & 0.40 & $1.5 \cdot 10^{2}$ & 2.20 & DS & [82] \\
\hline $\mathrm{I}_{5}$ & pts. (\%) & 0.43 & 0.38 & 0.15 & $3.7 \cdot 10^{2}$ & 3.00 & IS & {$[77,122]$} \\
\hline $\mathrm{I}_{6}$ & pts. (\%) & 0.45 & 0.42 & 0.35 & $3 \cdot 10^{2}$ & 1.85 & IS & {$[81,123,124]$} \\
\hline $\mathrm{I}_{7}$ & pts. (\%) & 0.55 & 0.35 & 0.40 & $0.60 \cdot 10^{2}$ & 3.00 & IS & {$[62-64]$} \\
\hline $\mathrm{I}_{8}$ & MJ & $2.05 \cdot 10^{4}$ & $1.40 \cdot 10^{4}$ & $1.50 \cdot 10^{4}$ & 0.40 & 1.80 & DCx & [84] \\
\hline $\mathrm{I}_{9}$ & $\mathrm{~kg}$ & $3.75 \cdot 10^{2}$ & $3.15 \cdot 10^{2}$ & $0.55 \cdot 10^{2}$ & 1.80 & 2.20 & DS & [74] \\
\hline $\mathrm{I}_{10}$ & $\mathrm{~kg} \mathrm{CO} 2$ & $1.60 \cdot 10^{3}$ & $1.28 \cdot 10^{3}$ & $1.40 \cdot 10^{3}$ & 0.80 & 1.40 & DCx & [84] \\
\hline
\end{tabular}

\section{Result and discussion}

The optimal solution is achieved when the areas of the kitchen and bathroom decrease by $0.23 \mathrm{~m}^{2}$ and $0.30 \mathrm{~m}^{2}$, respectively, and the area of the living room increases accordingly. As shown in Table 14, this layout presents minimum lengths of $\mathrm{WK}_{1}$ and $\mathrm{WB}_{2}$ by decreasing these by $0.15 \mathrm{~m}$ and $0.30 \mathrm{~m}$, respectively. Contrarily, the lengths of the dependent walls of the living room $\left(\mathrm{WL}_{1}\right.$ and $\left.\mathrm{WL}_{3}\right)$ are increased, that is, by sliding $\mathrm{WK}_{2}$ and $\mathrm{WB}_{2}$ in the direction that permits a minimisation of the kitchen and bathroom areas. The SI (0.66) of the optimal solution generated by the model showed an increase of $12 \%$ with respect to that used in Bam (SI $=0.54$ ), with the performances of the economic and environmental requirements being $28 \%$ and $42 \%$ greater (Fig. 6), respectively. The social requirement value decreased by approximately $1 \%$, owing to a slight reduction in the performances of the $\mathrm{I}_{4}$ and $\mathrm{I}_{6}$ indicators (Fig. 7).

However, the optimal solution had higher satisfaction values for the three social indicators, as shown in Fig. 7. Only the satisfaction values for two indicators $\left(\mathrm{I}_{4}\right.$ and $\mathrm{I}_{6}$ ) are lower than those of the initial layout, as shown in Fig. 7. Thus, the results demonstrate that the model works properly, and generates the optimal solution accurately.

Additionally, each one square metre of the construction materials used in the kitchen and bathroom led to more negative impacts in terms of the economic and environmental aspects. There was an expectation before running the model that minimum areas for the kitchen and bathroom would achieve the optimal solution. Finally, the model generated an alternative layout with the minimum areas of these two spaces. In this regard, it could certainly be noted that there is a direct correlation (relation) between the economic value and areas of

Table 14

Change ranges of the walls in the initial and optimal layouts.

\begin{tabular}{|c|c|c|c|}
\hline \multirow[t]{2}{*}{ Space } & \multirow[t]{2}{*}{ Partition } & \multicolumn{2}{|c|}{ Change Range (m) } \\
\hline & & $\begin{array}{l}\text { Initial } \\
\text { Layout } \\
\text { (Bam) }\end{array}$ & $\begin{array}{l}\text { Optimal } \\
\text { Layout }\end{array}$ \\
\hline \multirow[t]{3}{*}{ Living Room } & $\mathrm{WL}_{1}$ & 0.00 & +0.15 \\
\hline & $\mathrm{WL}_{2}$ & 0.00 & 0.00 \\
\hline & $\mathrm{WL}_{3}$ & 0.00 & +0.3 \\
\hline \multirow[t]{2}{*}{ Kitchen } & $\mathrm{WK}_{1} \&$ & 0.00 & -0.15 \\
\hline & $\begin{array}{l}\mathrm{WK}_{3} \\
\mathrm{WK}_{2} \& \\
\mathrm{WK}_{4}\end{array}$ & 0.00 & 0.00 \\
\hline \multirow[t]{2}{*}{ Bathroom } & $\mathrm{WB}_{1} \&$ & 0.00 & -0.3 \\
\hline & $\begin{array}{l}\mathrm{WB}_{3} \\
\mathrm{WB}_{2} \& \\
\mathrm{WB}_{4}\end{array}$ & 0.00 & 0.00 \\
\hline Entrance & $\mathrm{WE}_{4}$ & 0.00 & 0.00 \\
\hline
\end{tabular}

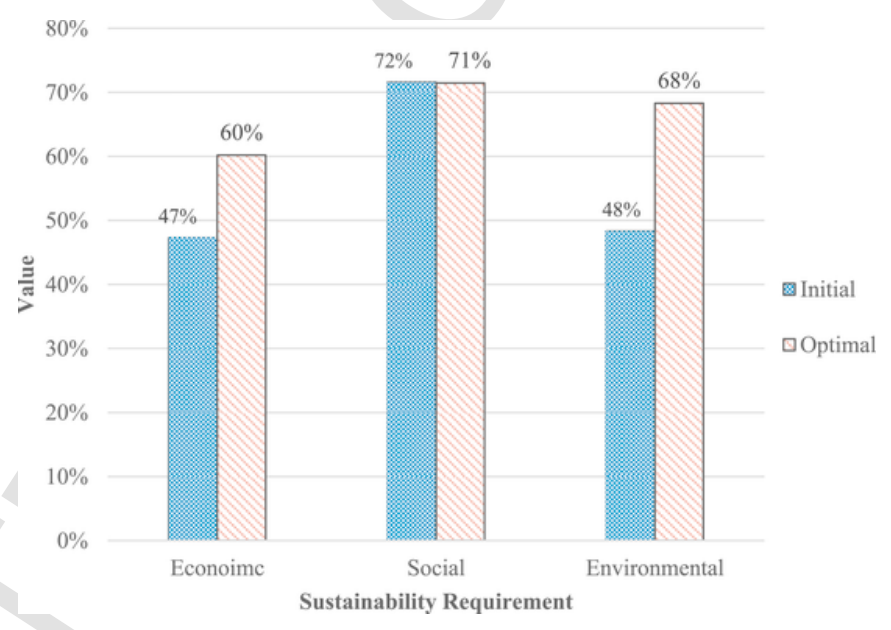

Fig. 6. Satisfaction values of the requirements for the initial and optimal solutions.

the kitchen and bathroom. Nevertheless, this relation does not always hold true for the environmental requirement.

The aforementioned fact demonstrates that the kitchen and bathroom areas need to be minimised in THUs as much as possible while respecting the building codes and DP requirements to achieve optimal SIs. In this case, it is possible to have several geometric designs. To this end, in addition to the optimal solution, the top-ten ranked solutions generated by the model are considered, as shown in Table 15. For instance, the second-ranked solution, which has an SI equal to 0.65 , has another geometric design. In this solution, the lengths of $\mathrm{WK}_{1}$ and $\mathrm{WK}_{2}$ decrease by $0.15 \mathrm{~m}$ and $0.05 \mathrm{~m}$, respectively. Furthermore, the lengths of $\mathrm{WB}_{1}$ and $\mathrm{WB}_{2}$ are changed by $-0.3 \mathrm{~m}$ and $+0.05 \mathrm{~m}$, respectively, as compared to the same edges of the initial layout.

In general, in all of the top-ten ranked solutions, the kitchen and bathroom areas are smaller than the areas of the same spaces in the initial layout. The highest satisfaction value for the social requirement among all ten solutions belongs to the fourth layout, as shown in Table 15. However, this layout includes lower values of the economic and environmental requirements as compared to the optimal solution. In this solution (fourth one), the decrease in the kitchen area is lower than in the other nine solutions, as shown in Table A. 1.

In addition to the consideration of the weights assigned by experts (Fig. 4), other weighting scenarios were analysed, with the purpose of both identifying those requirements that govern the sustainability performance and the layouts derived from each scenario. The weight sets were based on the experts' proposals, including those considered outliers.

On the one hand, the results shown in Fig. 8 confirm that the SI increases for scenarios in which the stakeholders are more sensitive to environmental and social requirements; this was expected because 


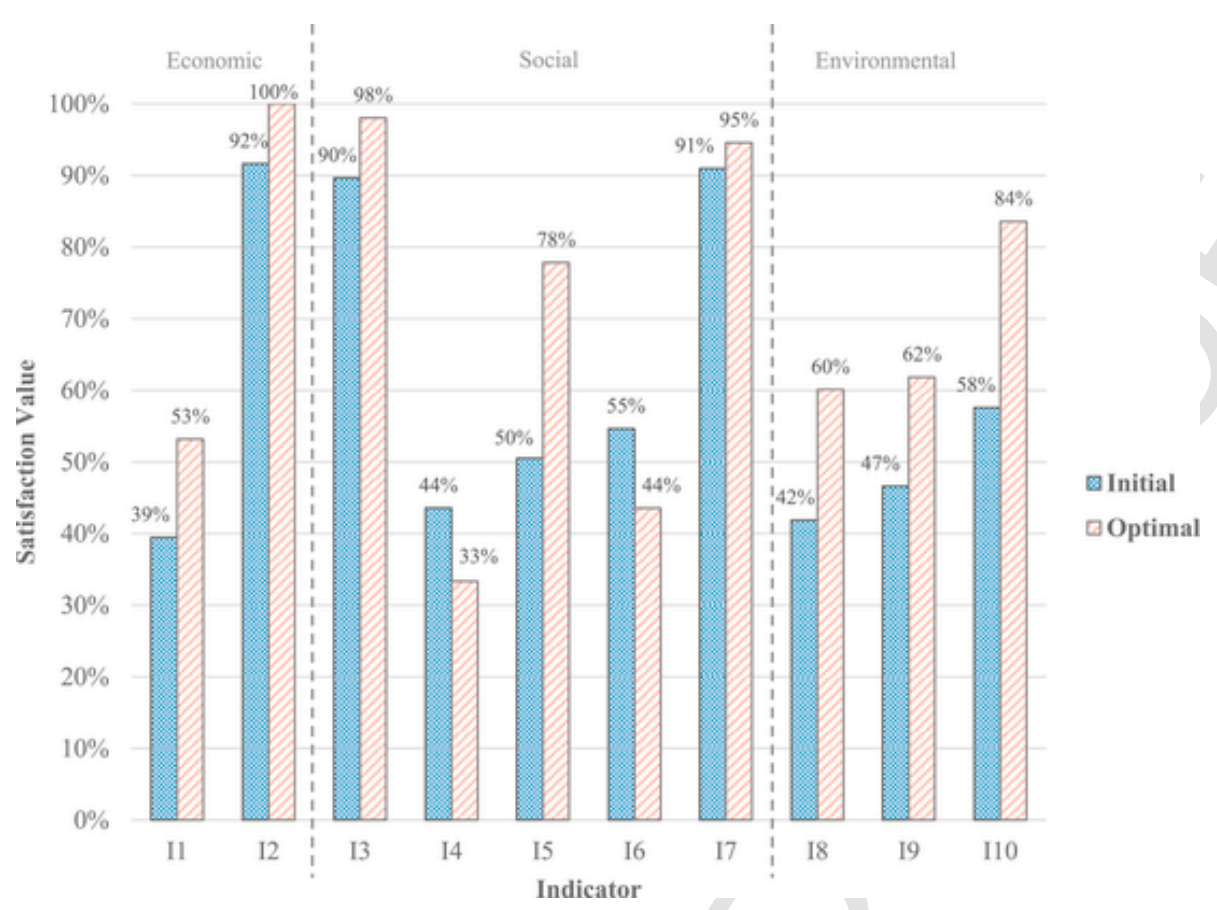

Fig. 7. Satisfaction values of the ten indicators for the initial and optimal solutions.

Table 15

SI of initial layout and top 10 ranked solutions by the model.

\begin{tabular}{|c|c|c|c|c|c|c|c|c|c|}
\hline \multirow[t]{3}{*}{ Rank } & \multirow[t]{3}{*}{ SI } & \multicolumn{3}{|l|}{ Value } & \multicolumn{5}{|c|}{ Change the length of the wall (m), compared to the initial one } \\
\hline & & \multirow[t]{2}{*}{ Economic } & \multirow[t]{2}{*}{ Social } & \multirow[t]{2}{*}{ Environmental } & \multicolumn{2}{|l|}{ Kitchen } & \multicolumn{2}{|c|}{ Bathroom } & \multirow{2}{*}{$\begin{array}{l}\text { Entrance } \\
\mathrm{WE}_{4}\end{array}$} \\
\hline & & & & & $\mathrm{WK}_{1}$ & $\mathrm{WK}_{2}$ & $\mathrm{WB}_{1}$ & $\mathrm{WB}_{2}$ & \\
\hline Initial & 0.5367 & 0.4728 & 0.7158 & 0.4832 & 0.00 & 0.00 & 0.00 & 0.00 & 0.00 \\
\hline 1 & 0.6551 & 0.6020 & 0.7147 & 0.6830 & -0.15 & 0.00 & -0.3 & 0.00 & 0.00 \\
\hline 2 & 0.6509 & 0.6021 & 0.7003 & 0.6810 & -0.15 & -0.05 & -0.3 & 0.05 & 0.00 \\
\hline 3 & 0.6468 & 0.6022 & 0.6858 & 0.6789 & -0.15 & -0.1 & -0.3 & 0.1 & 0.00 \\
\hline 4 & 0.6443 & 0.5878 & 0.7261 & 0.6608 & -0.1 & 0.00 & -0.3 & 0 & 0.00 \\
\hline 5 & 0.6426 & 0.6023 & 0.6714 & 0.6769 & -0.15 & -0.15 & -0.3 & 0.15 & 0.00 \\
\hline 6 & 0.6407 & 0.5883 & 0.7122 & 0.6597 & -0.15 & 0.00 & -0.3 & 0.05 & -0.05 \\
\hline 7 & 0.6407 & 0.5883 & 0.7122 & 0.6597 & -0.15 & 0.00 & -0.25 & 0.00 & 0.00 \\
\hline 8 & 0.6402 & 0.5879 & 0.7120 & 0.6589 & -0.1 & -0.05 & -0.3 & 0.05 & 0.00 \\
\hline 9 & 0.6385 & 0.6038 & 0.6572 & 0.6748 & -0.15 & -0.2 & -0.3 & 0.2 & 0.00 \\
\hline 10 & 0.6366 & 0.5885 & 0.6978 & 0.6577 & -0.15 & -0.05 & -0.3 & 0.1 & -0.05 \\
\hline
\end{tabular}

THU costs are commonly covered by public funds. However, it must be noted that, independent of the weights, the model generates the same geometry layout (Table 14) as the optimum. This can be assumed to be an indicator of the robustness of this optimum solution.

Other solutions with greater SIs can be generated by enlarging the ranges of the changes established in Table 3 . In this regard, SI $=0.87$ if the kitchen and bathroom areas of the initial layout are decreased by $0.975 \mathrm{~m}^{2}$ and $0.580 \mathrm{~m}^{2}$, respectively, and $1.296 \mathrm{~m}^{2}$ are added to the living room. Nevertheless, this layout is not acceptable, because the distribution and minimum area ratios do not meet building code requirements. Thus, the geometry layout (Table 14 ) found with SI $=0.66$ is the optimal layout that meets the stakeholders' preferences and the code requirements for the boundary conditions established in Table 3.

\section{Conclusions and perspectives}

A novel multi-objective sustainability-based approach for optimizing the geometric layout of the floor plans of THUs is presented in this research paper. The sustainability model is based upon the MIVES, which allows the quantification of the most representative indicators belonging to economic, environmental, and social requirements. For this purpose, both the value function concept and AHP processes were implemented to quantify the satisfaction and preferences (weights) of the stakeholders involved in the decision-making process. These methods were calibrated via questionnaires and within the context of experts' seminars and interviews, in which more than 500 people participated. The whole procedure was designed to guarantee the transparency, objectivity, and robustness of the results. However, it should be remarked that this research is based on the assessment of one THU's construction technology and, thus, further cases with more indica- 


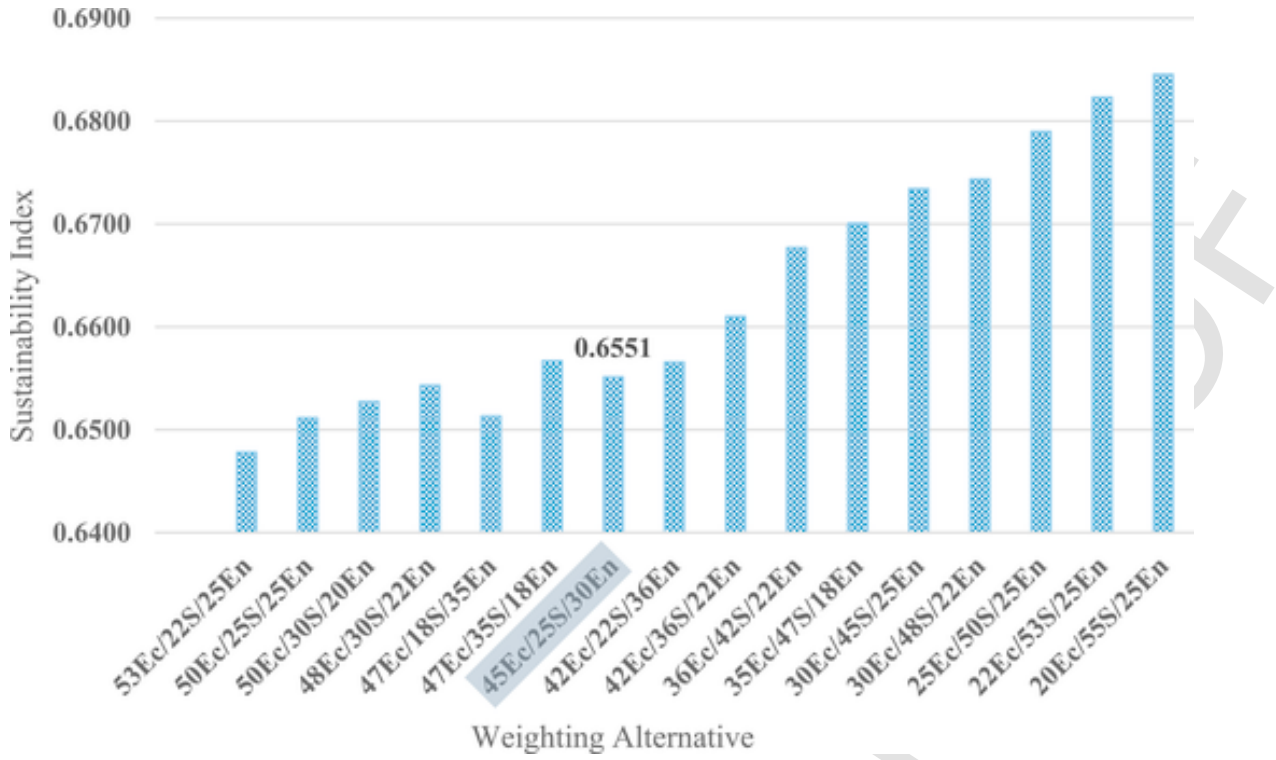

Fig. 8. SIs of optimal solutions generated by the model based on several weighting scenarios.

tors (ex., material off-cuts) should be analysed in order to generalize the outcomes of this study.

An optimization of the SI of the THUs used in the aftermath of the earthquake that occurred in 2003 in Bam (Iran) was conducted with the proposed model. Based on both the analysis of the obtained results and a parametric study, the following conclusions can be drawn:

- The layout that led to the maximum sustainability index (SI $=0.66$ ) consisted of reductions of $0.23 \mathrm{~m}^{2}$ in the kitchen area and $0.30 \mathrm{~m}^{2}$ in the bathroom space, with the living room area increasing by $0.53 \mathrm{~m}^{2}$. This solution represents a $12 \%$ sustainability index improvement with respect to the reference layout used in the Bam study case (with SI $=0.54)$.

- The economic and environmental performances of the optimal solution showed increases of $28 \%$ and $42 \%$ compared to the reference layout, respectively. The social performance decreased by a negligible $1 \%$. This improvement in both economic and environmental performances, while guaranteeing the same social acceptance, were found to be promising results when considering the number of THUs to be designed and constructed.

- The optimal solution detected was proven to be robust in different weighting scenarios (different stakeholders' preferences), and its sustainability performance was greater when social and environmental requirements drove the decision-making process.

The applicability of this approach can be extended to normal residential buildings, offices, and interior spaces with uses other than for THUs. For this purpose, the stakeholders and decision makers ought to include (if necessary) new indicators that prove to be representative of the particular boundary conditions. The weights should be also re-calibrated accordingly.

\section{Declaration of competing interests}

The authors declare that they have no known competing financial interests or personal relationships that could have appeared to influence the work reported in this paper.

\section{Acknowledgements}

The authors would like to acknowledge the kind support offered by professors and researchers from Shahid Beheshti University, Islamic Azad University, the Polytechnic University of Catalonia, and experts from the Housing Foundation of Islamic Republic of Iran (HFIR), who supported this paper for collecting and improving data. Additionally, the authors would like to thank UPC's Centre for Development Cooperation (CCD) for funding the authors (NO.: 2017-U006 and 2018-U012), which enabled the authors to follow and analyse the recovery program of Kermanshah earthquake.

\section{APPENDIX.}

Table A.1

Top 10 ranked solutions, including SIs, satisfaction values of indicators, and areas changes

Rank SI Indicator Satisfaction Value

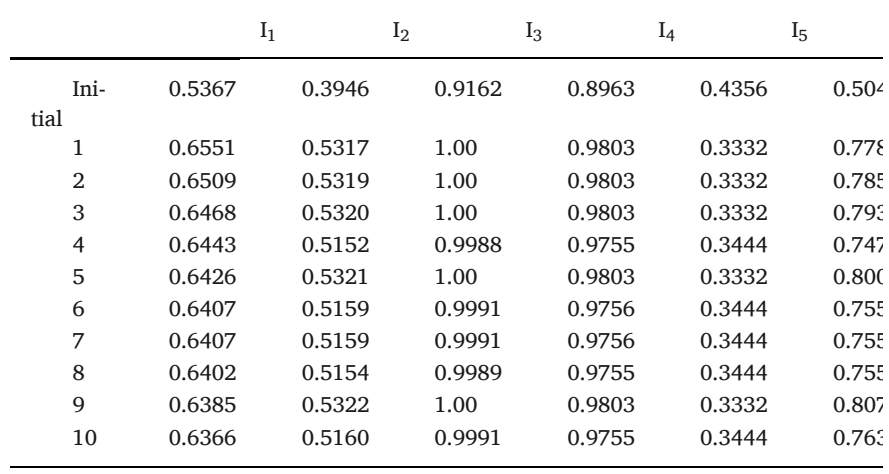

\section{References}

[1] A. Oliver-Smith, Disasters and Large-Scale Population Dislocations: International and National Responses, Oxford Research Encyclopedia of Natural Hazard, 2019, doi:10.1093/acrefore/9780199389407.013.224. 
[2] S. Collins, T. Corsellis, A. Vitale, Transitional Shelter: Understanding Shelter from the Emergency through Reconstruction and beyond, ALNAP, 2010. http://www. alnap.org/pool/files/innovationcasestudyno5-shelter.pdf.

[3] I. Davis, Shelter after Disaster, Oxford Polytechnic Press, Oxford, 1978.

[4] C. Johnson, Planning for temporary, Rebuilding After Disasters: From Emergency to Sustainability, Taylor \& Francis, 2009, pp. 70-87. http://ebooks.narotama.ac. id.

[5] T. Seike, Y. Kim, Y. Hosaka, S. Ida, T. Masuda, Intraregional reuse of emergency temporary housing in Japan, Sustain. Cities Soc. 42 (2018) 650-662, doi:10.1016/j.scs.2017.11.001

[6] D. Albadra, D. Coley, J. Hart, Toward healthy housing for the displaced, J. Architect. 23 (1) (2018) 115-136, doi:10.1080/13602365.2018.1424227.

[7] S. Platt, E. So, "Speed or deliberation: a comparison of post-disaster recovery in Japan, Turkey, and Chile, Disasters 41 (4) (2017) 696-727, doi:10.1111/ disa.12219.

[8] W.G. Peacock, N. Dash, Y. Zhang, S. Van Zandt, Post-disaster sheltering, temporary housing and permanent housing recovery, Handbook of Disaster Research, Springer, Cham, 2018, pp. 569-594.

[9] A. Biswas, A. Puriya, Comparative assessment of Indian post-disaster temporary housing strategies, J. Architect. Eng. 26 (1) (2020) 05019009, doi:10.1061/ (ASCE)AE.1943-5568.0000386.

[10] H. Arslan, Re-design, re-use and recycle of temporary houses, Build. Environ. 42 (2007) 400-406, doi:10.1016/j.buildenv.2005.07.032.

[11] C. Johnson, Impacts of prefabricated temporary housing after disasters: 1999 earthquakes in Turkey, Habitat Int. 31 (1) (2007) 36-52, doi:10.1016/ j.habitatint.2006.03.002.

[12] P.J. Chandler, Environmental Factors Influencing the Sitting of Temporary Housing, Louisiana State University, 2007.

[13] H. Arslan, N. Cosgun, Reuse and recycle potentials of the temporary houses after occupancy:Example of Duzce, Turkey, Build. Environ. 43 (2008) 702-709, doi:10.1016/j.buildenv.2007.01.051.

[14] O. El-Anwar, K. El-Rayes, A. Elnashai, Disasters, optimizing large-scale temporary housing arrangements after natural, Comput. Civ. Eng. 23 (2) (2009), doi:10.1061/(ASCE)0887-3801(2009)23:2(110).

[15] C. kelly, "strategic Site Selection and Management," World Wildlife Fund, American National Red Cross., San Francisco, 2010. http://green-recovery.org.

[16] L. Chen, A Web-Based System for Optimizing Post Disaster Temporary Housing Allocation, 2012.

[17] Z. Sadiqi, V. Coffey, B. Trigunarsyah, Rebuilding housing after a disaster: factors for failure, International Institute for Infrastructure, 2012 Renewal and.

[18] D. Félix, J.M. Branco, A. Feio, Temporary housing after disasters: a state of the ar survey, Habitat Int. (2013) 136-141, doi:10.1016/j.habitatint.2013.03.006.

[19] N. Atmaca, Life-cycle assessment of post-disaster temporary housing, Build. Res. Inf. 45 (5) (2017) 524-538, doi:10.1080/09613218.2015.1127116.

[20] T. Ramesh, R. Prakash, K.K. Shukla, Life cycle energy analysis of buildings: an overview, Energy Build. 42 (10) (2010) 1592-1600, doi:10.1016/ j.enbuild.2010.05.007.

[21] I.Z. Bribián, A.V. Capilla, A.A. Usón, Life cycle assessment of building materials comparative analysis of energy and environmental impacts and evaluation of the eco-efficiency improvement potential, Build. Environ. 46 (5) (2011) 1133-1140, doi:10.1016/j.buildenv.2010.12.002.

[22] G.W. Evans, J.M. McCoy, When buildings don't work: the role of architecture in human health, J. Environ. Psychol. 18 (1) (1998) 85-94, doi:10.1006/ jevp.1998.0089.

[23] Y.K. Yi, A.M. Malkawi, Optimizing building form for energy performance based on hierarchical geometry relation, Autom. ConStruct. 18 (6) (2009) 825-833, doi:10.1016/j.autcon.2009.03.006.

[24] A. Atmaca, N. Atmaca, Comparative life cycle energy and cost analysis of post-disaster temporary housings, Appl. Energy 171 (2016) 429-443, doi:10.1016/ j.apenergy.2016.03.058

[25] S.A. Arvin, D.H. House, Modeling architectural design objectives in physically based space planning, Autom. ConStruct. 11 (2) (2002) 213-225, doi:10.1016/ S0926-5805(00)00099-6.

[26] O. El-Anwar, K. El-Rayes, A. Elnashai, An automated system for optimizing post-disaster temporary housing allocation, Autom. ConStruct. 18 (7) (2009) 983-993, doi:10.1016/j.autcon.2009.05.003.

[27] S.A. Hosseini, O. Pons, A. de la Fuente, A combination of the Knapsack algorithm and MIVES for choosing optimal temporary housing site locations: a case study in Tehran, Int. J. Disaster Risk. Reduct. 27 (2018) 265-277, doi:10.1016/ j.ijdrr.2017.10.013

[28] O. El-Anwar, L. Chen, Maximizing the computational efficiency of temporary housing decision support following disasters, J. Comput. Civ. Eng. 28 (1) (2012) 113-123, doi:10.1061/(ASCE)CP.1943-5487.0000244.

[29] O. El-Anwar, Advancing optimization of hybrid housing development plans following disasters: achieving computational robustness, effectiveness, and efficiency, J. Comput. Civ. Eng. 27 (4) (2012) 358-369, doi:10.1061/ (ASCE)CP.1943-5487.0000234.

[30] R. Evins, A review of computational optimisation methods applied to sustainable building design, Renew. Sustain. Energy Rev. 22 (2013) 230-245, doi:10.1016/ j.rser.2013.02.004.

[31] M. Adamski, Optimization of the form of a building on an oval base, Build. Environ. 42 (4) (2007) 1632-1643, doi:10.1016/j.buildenv.2006.02.004.

[32] L.G. Caldas, L.K. Norford, A design optimization tool based on a genetic algorithm, Autom. ConStruct. 11 (2) (2002) 173-184, doi:10.1016/ S0926-5805(00)00096-0.

[33] A. Hasan, M. Vuolle, K. Sirén, Minimisation of life cycle cost of a detached house using combined simulation and optimisation, Build. Environ. 43 (12) (2008) 2022-2034, doi:10.1016/j.buildenv.2007.12.003.
[34] J.-T. Jin, J.-W. Jeong, Optimization of a free-form building shape to minimize external thermal load using genetic algorithm, Energy Build. 85 (2014) 473-482, doi:10.1016/j.enbuild.2014.09.080.

[35] J.H. Kämpf, D. Robinson, Optimisation of building form for solar energy utilisation using constrained evolutionary algorithms, Energy Build. 42 (6) (2010) 807-814, doi:10.1016/j.enbuild.2009.11.019.

[36] W. Marks, Multicriteria optimisation of shape of energy-saving buildings, Build. Environ. 32 (4) (1997) 331-339, doi:10.1016/S0360-1323(96)00065-0.

[37] J. Ordóñez, V. Modi, Optimizing $\mathrm{CO}_{2}$ emissions from heating and cooling and from the materials used in residential buildings, depending on their geometric characteristics, Build. Environ. 46 (11) (2011) 2161-2169, doi:10.1016/ j.buildenv.2011.04.030.

[38] W. Wang, H. Rivard, R.G. Zmeureanu, Optimizing building design with respect to life-cycle environmental impacts, Eighth International IBPSA Conference, 2003.

[39] W. Wang, R. Zmeureanu, H. Rivard, Applying multi-objective genetic algorithms in green building design optimization, Build. Environ. 40 (11) (2005) 1512-1525, doi:10.1016/j.buildenv.2004.11.017

[40] M. Balachandran, J.S. Gero, Dimensioning of architectural floor plans under conflicting objectives, Environ. Plann. Plann. Des. 14 (1) (1987) 29-37, doi:10.1068/ b140029.

[41] W.J. Mitchell, J.P. Steadman, R.S. Liggett, Synthesis and optimization of small rectangular floor plans, Environ. Plann. Plann. Des. 3 (1) (1976) 37-70, doi:10.1068/b030037

[42] P. Merrell, E. Schkufza, V. Koltu, Computer-generated residential building layouts, ACM Trans. Graph. 29 (6) (2010) 181.

[43] A.T.B. Bahrehmand, R. Marques, A. Evans, J. B, Optimizing layout using spatial quality metrics and user preferences, Graph. Model. 93 (2017) 25-38, doi:10.1016/j.gmod.2017.08.003.

[44] H. Yi, Y.K. Yi, T. Chan, Performance Based Architectural design optimization: automated 3D space Layout using simulated annealing, ASHRAE/IBPSA-Building Simulation Conference, 2014 Atlanta.

[45] F. Bao, D.-M. Yan, N.J. Mitra, P. Wonka, Generating and exploring good building layouts, ACM Trans. Graph. 32 (4) (2013) 122, doi:10.1145/2461912.2461977.

[46] P. Merrell, E. Schkufza, Z. Li, M. Agrawala, V. Koltun, Interactive furniture layout using interior design guidelines, ACM Transactions on Graphics, TOG, 2011.

[47] M. Ahmadizadeh, H. Shakib, On the December 26, 2003, southeastern Iran earthquake in Bam region, Eng. Struct. 26 (8) (2004) 1055-1070, doi:10.1016/ j.engstruct.2004.03.006.

[48] M. Ghafory-Ashtiany, M. Hosseini, Post-Bam earthquake: recovery and reconstruction, Nat. Hazards 44 (2008) 229-241, doi:10.1007/s11069-007-9108-3.

[49] M.H. Havaii, M. Hosseini, Bam earthquake from emergency response to reconstruction, Seismol. Earthq. Eng. 5 (4) (2004) 229-237. http://www.sid.ir/.

[50] Y. Kuwata, S. Takada, M. Bastami, Building damage and human casualties during the Bam-Iran earthquake, Asian. J. Civ. Eng. 6 (1-2) (2005) 1-19.

[51] A.R. Anafpour, Bam earthquake, Iran: lessons on the seismic behaviour of building structures, 14th World Conference on Earthquake Engineering, 2008 Beijing, China.

[52] B. Khazai, E. Hausler, Intermediate shelters in Bam and permanent shelter reconstruction in villages following the 2003 Bam, Iran, earthquake, Earthq. Spectra 21 (2005) 487-511, doi:10.1193/1.2098907.

[53] M. Rafieian, A. Asgary, Impacts of temporary housing on housing reconstruction after the Bam earthquake, Disaster Prev. Manag.: Int. J. 22 (1) (2013) 63-74, doi:10.1108/09653561311301989.

[54] O. Rezaifar, M. Kabir, M. Taribakhsh, A. Tehranian, Dynamic behaviour of 3D-panel single-storey system using shaking table testing, Eng. Struct. 30 (2) (2008) 318-337, doi:10.1016/j.engstruct.2007.03.019.

[55] S.A. Hosseini, A. de la Fuente, O. Pons, Multi-criteria decision-making method for assessing the sustainability of post-disaster temporary housing units technologies: a case study in Bam, 2003, Sustain. Cities Soc. 20 (2016) 38, doi:10.1016/ j.scs.2015.09.012.

[56] A. Khatam, The destruction of Bam and its reconstruction following the earthquake of December 2003, Cities 23 (6) (2006) 462-464, doi:10.1016/ j.cities.2006.08.008

[57] A.D. Radford, J.S. Gero, On optimization in computer aided architectural design, Build. Environ. 15 (2) (1980) 73-80, doi:10.1016/0360-1323(80)90011-6.

[58] P. Civicioglu, Backtracking search optimization algorithm for numerical optimization problems, Appl. Math. Comput. 219 (15) (2013) 8121-8144, doi:10.1016/ j.amc.2013.02.017

[59] P. Van Beek, Backtracking search algorithms, Found. Artif. Intell. 2 (2006) 85-134, doi:10.1016/S1574-6526(06)80008-8.

[60] UNHCR, Handbook for Emergencies, United Nations High Commissioner for Refugees, 2015 Genova.

[61] IFRC, Post-disaster shelters: ten designs, International Federation of Red Crossand Red Crescent Societies, Geneva, 2013.

[62] INBC part 4, Iranian National Building Code Part, 4, Ministry of Housing and Urbanism IRI, 2013 ([In Persian])

[63] IBC, International Building Code 2015, International Code Council, 2014.

[64] Department for Communities and Local Government, "Technical Housing Standards - Nationally Described Space Standard, 2015

[65] S.A. Hosseini, A. de la Fuente, O. Pons, Multicriteria decision-making method for sustainable site location of post-disaster temporary housing in urban areas, J. Construct. Eng. Manag. 142 (9) (2016) 04016036, doi:10.1061/ (ASCE)CO.1943-7862.0001137.

[66] A. de la Fuente, M. Casanovas-Rubio, O. Pons, J. Armengou, Sustainability of column-supported RC slabs: fiber reinforcement as an alternative, J. Construct. Eng. Manag. 145 (7) (2019) 04019042, doi:10.1061/(ASCE)CO.1943-7862.0001667.

[67] O. Pons, J. Franquesa, S.M. Hosseini, Integrated value model to assess the sustainability of active learning activities and strategies in architecture lectures for large groups, Sustainability 11 (10) (2019) 2917, doi:10.3390/su11102917. 
[68] O. Pons, A. Aguado, Integrated value model for sustainable assessment applied to technologies used to build schools in Catalonia, Spain, Build. Environ. 53 (2012) 49-58, doi:10.1016/j.buildenv.2012.01.007.

[69] A. del Caño, D. Gómez, M.P. de la Cruz, Uncertainty analysis in the sustainable design of concrete structures: a probabilistic method, Construct. Build. Mater. 37 (2012) 865-873, doi:10.1016/j.conbuildmat.2012.04.020.

[70] G. Gilani, A. Blanco, A.D. Fuente, A new sustainability assessment approach based on stakeholder's satisfaction for building facades, Energy Procedia 115 (2017) 50-58, doi:10.1016/j.egypro.2017.05.006.

[71] A. de la Fuente, O. Pons, A. Josa, A. Aguado, Multi-Criteria Decision Making in the sustainability assessment of sewerage pipe systems, J. Clean. Prod. 112 (2016) 4762-4770, doi:10.1016/j.jclepro.2015.07.002.

[72] M. del Mar Casanovas-Rubio, P. Pujadas, F. Pardo-Bosch, A. Blanco, A. Aguado, Sustainability assessment of trenches including the new eco-trench: a multi-criteria decision-making tool, J. Clean. Prod. 238 (2019), doi:10.1016/ j.jclepro.2019.117957 117957.

[73] P. Lufkin, D. Abate, J. Miller, The Whitestone Facility Maintenance and Repair Cost Reference 2010-2011, 15th Annual Edition, Whitestone Research, Santa Barbara, CA, USA, 2010.

[74] Tehran"Pricing Schedule of Buildings in Iran 2004," Vice-President for Strategic Planning and Supervision of Iran, 2004 ([In Persian]).

[75] D. Abate, M. Towers, R. Dotz, L. Romani, The Whitestone Facility Maintenance and Repair Cost Reference 2009-2010, Whitestone Research, California, 2009.

[76] K.M. Cochran, Construction and Demolition Debris Recycling: Methods, Markets, and Policy, 2006.

[77] INBC part 18, Iranian National Building Code Part18, Ministry of Housing and Ur banism IRI, 2009 ([In Persian]).

[78] N. Garg, O. Sharma, S. Maji, Design considerations of building elements for traffic and aircraft noise abatement, Indian J. Pure Appl. Phys. 49 (7) (2011) 437-450.

[79] building regulations, Approved Document E - Resistance to the Passage of Sound, 2010.

[80] Issue No. 613, "Cold formed light steel structures design and Construction code (nonstructural)," Islamic Republic of Iran Vice Presidency for Strategic Planning and Supervision, 2013. ([In Persian]).

[81] IBC, International Building Code, International Code Council, Inc., 2009.

[82] INBC part 19, Iranian National Building Code Part19, Ministry of Housing and Urbanism IRI, 2011 ([In Persian]).

[83] A. Papadopoulos, State of the art in thermal insulation materials and aims for future developments, Energy Build. 37 (1) (2005) 77-86, doi:10.1016/ j.enbuild.2004.05.006.

[84] G. Hammond, C. Jones, Inventory of Carbon \& Energy (ICE), University of Bath, 2011.

[85] J. Solís-Guzmán, M. Marrero, M.V. Montes-Delgado, A. Ramírez-de-Arellano, A Spanish model for quantification and management of construction waste, Waste Manag. 29 (9) (2009) 2542-2548, doi:10.1016/j.wasman.2009.05.009.

[86] K.S. Prairie Village, Characterization of Building-Related Construction and Demolition Debris in the United States, The US Environmental Protection Agency Municipal and Industrial Solid Waste Division Office of Solid Waste, 1998. https:// www.epa.gov.

[87] A. Asgari, T. Ghorbanian, N. Yousefi, D. Dadashzadeh, F. Khalili, A. Bagheri, M. Raei, A.H. Mahvi, Quality and quantity of construction and demolition waste in Tehran, J. Environ. Health. Sci. Eng. 15 (1) (2017) 14, doi:10.1186/ s40201-017-0276-0.

[88] S.D. Schuette, R.W. Liska, Building Construction Estimating, McGraw-Hill College, 1994.

[89] T. Pinto, V. Agopyan, Construction wastes as raw materials for low cost construction products, First International Conference of CIB, 1994 Tampa, Florida.

[90] M.D. Saghafi, Z.A.H. Teshnizi, Building deconstruction and material recovery in Iran: an analysis of major determinants, Procedia. Eng. 21 (2011) 853-863, doi:10.1016/j.proeng.2011.11.2087.

[91] Z. Chen, H. Li, C.T. Wong, An application of bar-code system for reducing construction wastes, Autom. ConStruct. 11 (5) (2002) 521-533, doi:10.1016/ S0926-5805(01)00063-2.

[92] B.A.G. Bossink, H.J.H. Brouwers, Construction waste: quantification and source evaluation, J. Construct. Eng. Manag. 122 (1) (1996) 55-60, doi:10.1061/ (ASCE)0733-9364(1996)122:1(55)

[93] D.J. Harris, A quantitative approach to the assessment of the environmental impact of building materials, Build. Environ. 34 (6) (1999) 751-758, doi:10.1016/ S0360-1323(98)00058-4.

[94] B. Addis, Building with Reclaimed Components and Materials: a Design Handbook for Reuse and Recycling, Routledge, London, 2012, p. 224.

[95] Y.-K. Wen, Y.J. Kang, Minimum building life-cycle cost design criteria. I: Methodology, J. Struct. Eng. 127 (3) (2001) 330-337, doi:10.1061/ (ASCE)0733-9445(2001)127:3(330)

[96] P.F. Kaming, P.O. Olomolaiye, G.D. Holt, F.C. Harris, Factors influencing construction time and cost overruns on high-rise projects in Indonesia, Construct. Manag. Econ. 15 (1) (1997) 83-94, doi:10.1080/014461997373132.

[97] P. Gluch, H. Baumann, The life cycle costing (LCC) approach: a conceptual discussion of its usefulness for environmental decision-making, Build. Environ. 39 (5) (2004) 571-580, doi:10.1016/j.buildenv.2003.10.008.
[98] M.A. El-Haram, M.W. Horner, Factors affecting housing maintenance cost, J. Qual. Mainten. Eng. 8 (2) (2002) 115-123, doi:10.1108/13552510210430008.

[99] H. Wallbaum, Y. Ostermeyer, C. Salzer, E.Z. Escamilla, Indicator based sustainability assessment tool for affordable housing construction technologies, Ecol. Indicat. 18 (2012) 353-364, doi:10.1016/j.ecolind.2011.12.005.

[100] S.A. Assaf, S. Al-Hejji, Causes of delay in large construction projects, Int. J. Proj. Manag. 24 (4) (2006) 349-357, doi:10.1016/j.jjproman.2005.11.010.

[101] D.W. Chan, M.M. Kumaraswamy, An evaluation of construction time performance in the building industry, Build. Environ. 31 (6) (1996) 569-578, doi:10.1016/ 0360-1323(96)00031-5.

[102] G.J. Hoffman, A.E. Thal Jr., T.S. Webb, J.D. Weir, Estimating performance time for construction projects, J. Manag. Eng. 23 (4) (2007) 193-199, doi:10.1061/ (ASCE)0742-597X(2007)23:4(193).

[103] D.W. Chan, M.M. Kumaraswamy, Compressing construction durations: lessons learned from Hong Kong building projects, Int. J. Proj. Manag. 20 (1) (2002) 23-35, doi:10.1016/S0263-7863(00)00032-6.

[104] R. De Dear, G.S. Brager, Developing an Adaptive Model of Thermal Comfort and Preference, 1998.

[105] M. Taleghani, M. Tenpierik, S. Kurvers, A.V.D. Dobbelsteen, A review into therma comfort in buildings, Renew. Sustain. Energy Rev. 26 (2013) 201-215, doi:10.1016/j.rser.2013.05.050.

[106] J.F. Nicol, M.A. Humphreys, Adaptive thermal comfort and sustainable thermal standards for buildings, Energy Build. 34 (6) (2002) 563-572, doi:10.1016/ S0378-7788(02)00006-3.

[107] L. Shen, J.L. Hao, V.W. Tam, H. Yao, A checklist for assessing sustainability performance of construction projects, J. Civ. Eng. Manag. 13 (4) (2007) 273-281, doi:10.1080/13923730.2007.9636447.

[108] A.W.A. Hammad, A. Akbarnezhad, D. Rey, A multi-objective mixed integer nonlinear programming model for construction site layout planning to minimise noise pollution and transport costs, Autom. ConStruct. 61 (2016) 73-85, doi:10.1016/ j.autcon.2015.10.010.

[109] BSI British Standards, British Standards: Code of Practice for Noise and Vibration Control on Construction and Open Sites-Part 1: Noise, BS 5228, BSI British Standards Institution, 2008.

[110] G.K. Oral, A.K. Yener, N.T. Bayazit, Building envelope design with the objective to ensure thermal, visual and acoustic comfort conditions, Build. Environ. 39 (3) (2004) 281-287, doi:10.1016/S0360-1323(03)00141-0.

[111] M. Kobes, I. Helsloot, B.D. Vries, J.G. Post, Building safety and human behaviou in fire: a literature review, Fire Saf. J. 45 (1) (2010) 1-11, doi:10.1016/ j.firesaf.2009.08.005.

[112] N. Tas, N. Cosgun, M. Tas, A qualitative evaluation of the after earthquake permanent housings in Turkey in terms of user satisfaction - kocaeli, Gundogdu Permanent Housing model, Build. Environ. 42 (9) (2007) 3418-3431, doi:10.1016/ j.buildenv.2006.09.002

[113] L. Pérez-Lombard, J. Ortiz, C. Pout, A review on buildings energy consumption in formation, Energy Build. 40 (3) (2008) 394-398, doi:10.1016/ j.enbuild.2007.03.007.

[114] A. Invidiata, M. Lavagna, E. Ghisi, Selecting design strategies using multi-criteria decision making to improve the sustainability of buildings, Build. Environ. 139 (2018) 58-68, doi:10.1016/j.buildenv.2018.04.041.

[115] H. Zhao, F. Magoulès, A review on the prediction of building energy consumption, Renew. Sustain. Energy Rev. 16 (6) (2012) 3586-3592, doi:10.1016/ j.rser.2012.02.049.

[116] M. Osmani, J. Glass, A.D. Price, Architects' perspectives on construction waste reduction by design, Waste Manag. 28 (7) (2008) 1147-1158, doi:10.1016/ j.wasman.2007.05.011.

[117] H. Yuan, Key indicators for assessing the effectiveness of waste management in construction projects, Ecol. Indicat. 24 (2013) 476-484, doi:10.1016/ j.ecolind.2012.07.022.

[118] H. Yan, Q. Shen, L.C. Fan, Y. Wang, L. Zhang, Greenhouse gas emissions in building construction: a case study of One Peking in Hong Kong, Build. Environ. 45 (4) (2010) 949-955, doi:10.1016/j.buildenv.2009.09.014.

[119] R.J. Cole, Energy and greenhouse gas emissions associated with the construction of alternative structural systems, Build. Environ. 34 (3) (1998) 335-348, doi:10.1016/S0360-1323(98)00020-1.

[120] B. Alarcon, A. Aguado, R. Manga, A. Josa, A value function for assessing sustainability: application to industrial buildings, Sustainability 3 (1) (2011) 35-50, doi:10.3390/su3010035

[121] Housing Foundation of Islamic Republic of Iran (HFIR), Documentation of Bam Earthquake Reconstruction, 2013 ([In Persain]).

[122] M. Frontczak, R.V. Andersen, P. Wargocki, Questionnaire survey on factors influencing comfort with indoor environmental quality in Danish housing, Build. Environ. 50 (2012) 56-64, doi:10.1016/j.buildenv.2011.10.012.

[123] INBC part 3, Iranian National Building Code Part 3, Ministry of Housing and Urbanism IRI, 2013 ([In Persain])

[124] Fire-Resistance and Sound-Insulation Ratings for Walls, Partitions, and Floors, united state department of commerce, Washington, 1994. http://fire.nist.gov.

[125] T.L. Saaty, How to make a decision: the analytic hierarchy process, Eur. J. Oper. Res. 48 (1) (1990) 9-26, doi:10.1016/0377-2217(90)90057-I. 